UC-350

\title{
IMPACT EVALUATION FOR THE MANUFACTURED HOUSING ACQUISITION PROGRAM (MAP)
}
A. D. Lee
Z. T. Taylor
D. W. Schrock
L. J. Sandahl
R. I. Chin
D. C. Kavanaugh

October 1995

Prepared for Sheila Riewer, Office of Marketing, Conservation, and Production Measurement and Evaluation Section the Bonneville Power Administration under a Related Services Agreement with the U.S. Department of Energy Contract DE-AC06-76RLO 1830 
. 


\section{EXECUTIVE SUMMARY}

This report presents the results of an impact evaluation of the Manufactured Housing Acquisition Program. This evaluation was conducted for Bonneville by Pacific Northwest Laboratory to determine MAP's energy impacts and cost-effectiveness. Two other reports supplement this overall report on the evaluation. Lee et al. (1995) provides technical details of the study. Sandahl, Lee, and Chin (1995) presents detailed information about the home owner survey conducted for this evaluation.

\section{DATA COLLECTION}

To estimate MAP savings we developed MAP and baseline home samples. We conducted telephone interviews to collect home and owner information for both homes. We completed 167 MAP occupant interviews and collected 134 utility billing release forms. For the baseline homes, we completed 183 interviews and obtained signed utility billing release forms from 123 respondents.

\section{ANALYSIS OVERVIEW}

We conducted a three-tiered analysis of the utility billing data to estimate program electricity savings. The first (a raw billing data comparison and simple regression analysis) and second (PRISM) tier analyses provided useful findings for the third-tier analysis by which program savings were estimated.

The third-tier approach used a conditional demand type regression analysis to analyze monthly energy consumption, taking into account significant factors likely to influence electricity usage. We used the regression results to estimate energy savings under "normal" weather conditions for each climate zone.

For purposes of estimating savings we had to define a comparison home based on typical characteristics. The "pre-MAP baseline" home represents a home with dimensions typical of current homes, but with an efficiency level typical of homes built prior to MAP. The electricity savings estimates were very sensitive to assumptions made about the use of non-electric (primarily wood) space heat; about $20 \%$ of our combined sample of homes used some non-electric heat. We found no consistent evidence that MAP homes used non-electric heat more often. 
We used two approaches to estimate energy savings impacts of MAP. In the first, we calculated electricity savings based on the overall observed mix of heating types. In the second case, we calculated energy savings based on the assumption that all heating was supplied by an electric resistance furnace.

The savings estimates were based on the third-tier, regression results. Acquisition energy savings were calculated as the energy consumption difference between preprogram baseline and MAP homes. These were the direct energy savings associated with homes built under MAP. MAP, however, had significant market transformation effects not accounted for by the acquisition savings.

MAP occurred in two phases. During Phase 1, April 1992 through October 1994, the original national HUD code was in effect and utilities paid manufacturers $\$ 2,500$ for each MAP home. Phase 2 started after October 1994, when a new, more efficient HUD code went into effect and the payment declined to $\$ 1,500$. We estimated energy savings for homes built during each phase. Our estimates of regional average energy savings for homes built during Phase 1 varied from about 3,800 to $4,700 \mathrm{kWh} /$ year and for homes built during Phase 2 varied from about 2,500 to $3,000 \mathrm{kWh} /$ year.

\section{LEVELIZED COSTS}

We determined cost-effectiveness by calculating levelized costs using a methodology published by Bonneville. Under one perspective, levelized costs were based on regional system costs. From this perspective, electricity savings were acquired for MAP homes at a regional average cost of about $1.7 \mathrm{c} / \mathrm{kWh}(17 \mathrm{mills} / \mathrm{kWh})$. From the second perspective, the program costs borne by Bonneville for MAP were about $2.0 \mathrm{G} / \mathrm{kWh}(20 \mathrm{mills} / \mathrm{kWh})$. Overall, these costs were low enough that the program, based on acquisition energy savings alone, was cost-effective.

\section{MARKET TRANSFORMATION}

Although too early to tell definitively, MAP appeared to have made fundamental changes in the market for energy efficient manufactured homes in the Pacific Northwest. More than 50,000 electrically heated manufactured homes sited in the region since April 1992 have been built to MAP specifications. Consumers have come to expect the MAP features and dealers have become used to selling them. Although 
it was unknown exactly what the market would look like with the end of MAP, the program appeared to have caused a significant, lasting transformation.

We analyzed potential market transformation effects from a conceptual viewpoint. Our results suggested that MAP's market transformation benefits probably reduced the levelized cost to utilities by $40 \%$ or more.

\section{CONCLUSIONS AND RECOMMENDATIONS}

Our results indicated that MAP was cost-effective overall, even when viewed as just an electricity savings acquisition program. Cost-effectiveness did vary by climate zone, but the program was cost-effective in all cases from the regional system perspective. From the Bonneville system perspective, the cost-effectiveness in the mildest climate zone (climate zone 1) was questionable. Accounting for the likely large market transformation impacts, the program was unquestionably cost-effective in all zones.

This study raised the following important analytic issues:

- Cost-effectiveness depends significantly on the energy efficiency assumed for pre-program baseline manufactured homes

- Pre-program savings estimates were considerably larger than our estimates based on billing data from MAP and non-MAP homes

- The relationship between temperature and energy consumption in regression analysis models needs further investigation

- Zoning may diminish the effect of building envelope efficiency improvements

- Mechanical ventilation may have affected energy savings of MAP homes

In addition to analytic findings, this study produced the following program design and policy findings and observations:

- On the average, the utility payments to manufacturers appeared to have exceeded the manufacturers' (and even the wholesale) incremental wholesale costs associated with MAP homes: it is likely that smaller utility payments could have accomplished the program purposes while reducing program costs 
- MAP appears to have caused a significant transformation in the manufactured housing market in the Pacific Northwest: further studies should be conducted to document and verify the market transformation effects caused by MAP

- MAP ended sooner than anticipated and with less preparation than desired: an off-the-shelf strategy to transition out of the program would have helped maintain the good relationships and positive expectations established by the program and future programs, especially market transformation programs, should incorporate a transition strategy in the initial program plan 


\section{CONTENTS}

EXECUTIVE SUMMARY $\ldots \ldots \ldots \ldots \ldots \ldots \ldots \ldots \ldots$ iii

1.0 OVERVIEW AND SUMMARY OF FINDINGS $\ldots \ldots \ldots \ldots \ldots \ldots \ldots$

1.1 MANUFACTURED HOUSING ACQUISITION PROGRAM $\ldots \ldots \ldots .1 .0$

1.2 EVALUATION PURPOSE AND OVERVIEW $\ldots \ldots \ldots \ldots \ldots \ldots \ldots$

1.3 SUMMARY FINDINGS $\ldots \ldots \ldots \ldots \ldots \ldots \ldots \ldots \ldots \ldots \ldots \ldots$

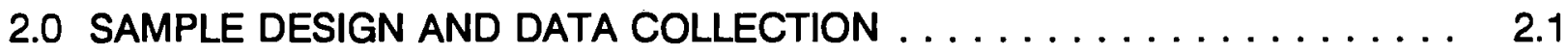

2.1 SAMPLE DESIGN $\ldots \ldots \ldots \ldots \ldots \ldots \ldots \ldots \ldots \ldots \ldots \ldots \ldots \ldots \ldots$

2.2 DATA COLLECTION $\ldots \ldots \ldots \ldots \ldots \ldots \ldots \ldots \ldots \ldots .2$

3.0 OVERVIEW OF ANALYSES $\ldots \ldots \ldots \ldots \ldots \ldots \ldots \ldots \ldots \ldots \ldots .1$

3.1 TIERED ANALYSIS APPROACH: BILLING DATA AND PRISM ANALYSES RESULTS $\ldots \ldots \ldots \ldots \ldots \ldots \ldots \ldots \ldots \ldots \ldots \ldots \ldots \ldots$

3.2 THIRD TIER ANALYSIS: REGRESSION ANALYSIS $\ldots \ldots \ldots \ldots .6$

3.4 ENERGY SAVINGS ANALYSIS $\ldots \ldots \ldots \ldots \ldots \ldots \ldots \ldots \ldots .8$

3.5 COST-EFFECTIVENESS ANALYSIS $\ldots \ldots \ldots \ldots \ldots \ldots \ldots .13$

4.0 ACQUISITION ENERGY SAVINGS AND COST-EFFECTIVENESS RESULTS 4.1

4.1 ACQUISITION ENERGY SAVINGS ESTIMATES $\ldots \ldots \ldots \ldots \ldots . .1$

4.2 ACQUISITION COST-EFFECTIVENESS $\ldots \ldots \ldots \ldots \ldots \ldots \ldots .3$

5.0 MARKET TRANSFORMATION IMPLICATIONS $\ldots \ldots \ldots \ldots \ldots \ldots \ldots . .1$

6.0 FINDINGS AND RECOMMENDATIONS $\ldots \ldots \ldots \ldots \ldots \ldots \ldots \ldots .1$ 
6.1 EVALUATION FINDINGS $\ldots \ldots \ldots \ldots \ldots \ldots \ldots \ldots \ldots \ldots \ldots .1$

6.2 COMPARISON WITH OTHER RESULTS $\ldots \ldots \ldots \ldots \ldots \ldots \ldots .2$

6.3 CONCLUSIONS AND RECOMMENDATIONS $\ldots \ldots \ldots \ldots \ldots .3$

7.0 REFERENCES $\ldots \ldots \ldots \ldots \ldots \ldots \ldots \ldots \ldots \ldots \ldots \ldots \ldots \ldots \ldots \ldots \ldots \ldots$ 


\section{FIGURES}

5.1 Components of Market Transformation . . . . . . . $\ldots \ldots \ldots \ldots$

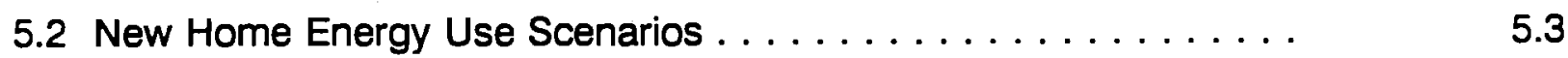

5.3 Acquisition and Market Transformation Energy Savings. . . . . . . . 5.4

\section{TABLES}

1.1 Manufactured Home Distribution by Climate Zone $\ldots \ldots \ldots \ldots \ldots \ldots$

1.2 Characteristics of Homes in Samples $\ldots \ldots \ldots \ldots \ldots \ldots \ldots \ldots \ldots$

1.3 Occupant Survey Responses $\ldots \ldots \ldots \ldots \ldots \ldots \ldots \ldots \ldots \ldots \ldots$

1.4 Mean Annual Electricity Consumption Estimates $\ldots \ldots \ldots \ldots \ldots \ldots 1.8$

1.5 MAP Acquisition Energy Savings, kWh/year Per Home $\ldots \ldots \ldots \ldots$

1.6 MAP Acquisition Levelized Costs, $\mathrm{c} / \mathrm{kWh}(1993 \$) \ldots \ldots \ldots \ldots \ldots$

3.1 Simplified Billing Data Analysis Results $\ldots \ldots \ldots \ldots \ldots \ldots \ldots \ldots \ldots .2$

3.2 PRISM Results, Unfiltered Data $\ldots \ldots \ldots \ldots \ldots \ldots \ldots \ldots \ldots \ldots \ldots$

3.3 PRISM Results, Filtered Data $\ldots \ldots \ldots \ldots \ldots \ldots \ldots \ldots \ldots \ldots \ldots$

3.4 Definition of Terms in Equation $3.1 \ldots \ldots \ldots \ldots \ldots \ldots \ldots \ldots \ldots \ldots$

3.5 Estimated Coefficients in Equation $3.1 \ldots \ldots \ldots \ldots \ldots \ldots \ldots \ldots \ldots \ldots$

4.1 MAP Acquisition Energy Savings, kWh/year per home ... . . . . . 4.1

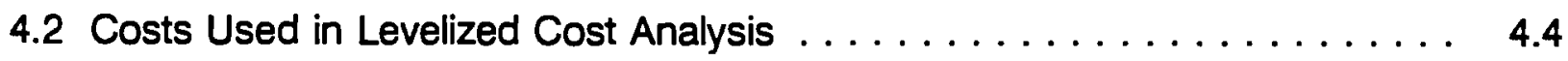


4.3 MAP Acquisition Levelized Costs, $\& / \mathrm{kWh}(1993 \$) \ldots \ldots \ldots \ldots$

5.1 Market Transformation Effect on Bonneville System Levelized MAP Costs . . . . . . . . . . . . . . . . . . . . . . 5.5 


\subsection{OVERVIEW AND SUMMARY OF FINDINGS}

HUD-code manufactured homes (commonly called "mobile homes") constitute about $25 \%$ of the new housing units in the Pacific Northwest. These manufactured homes represent $40 \%$ of all new, electrically heated single-family homes in the region. The U.S. Department of Housing and Urban Development (HUD) sets national preemptive construction standards, including energy-efficiency requirements, for manufactured homes; therefore, local governments are prevented from establishing tighter efficiency requirements. Until October 1994, a relatively low efficiency requirement set in 1976 was in place for manufactured homes.

Because manufactured homes are such a large proportion of new homes, and because they are relatively inefficient, the Bonneville Power Administration (Bonneville) has conducted a series of projects and programs since 1982 to upgrade their efficiency. Gilbertson et al. (1993) document these programs. These activities led to the design and initiation of the Manufactured Housing Acquisition Program (MAP) in 1992.

This report presents the results of an impact evaluation of MAP. This evaluation was conducted for Bonneville by Pacific Northwest Laboratory to determine the energy impacts and cost-effectiveness of MAP.

\subsection{MANUFACTURED HOUSING ACQUISITION PROGRAM}

Bonneville and the regional utilities and manufacturers began MAP in April 1992. The program was phased in over several months.

There are four unique cornerstones of the program: 1) It is a voluntary agreement. 2) The payment goes directly to manufacturers. 3) The payment is intended to cover costs of efficiency improvements that buyers may not find cost-effective, but that are cost-effective to the region as a whole. 4) The program is intended to permanently change, or transform, the energy-efficient manufactured home market.

Because of the preemptive HUD code, Bonneville sought a voluntary mechanism for improving energy efficiency. Although not mandatory, all manufacturers and almost all utilities chose to participate in MAP. Competitive pressures and the benefits of regional advertising and recognition convinced all home manufacturers to participate. 
MAP relied on utility payments to manufacturers, rather than to home buyers, because early studies (e.g., Harkreader, Lee, and Sherman 1987) showed that payments to manufacturers for energy-efficiency upgrades were likely to have more financial leverage than incentives to buyers. This is because the manufacturers mark up material costs about $46 \%$ to arrive at the wholesale cost, and the dealers who sell the homes add an additional mark up of about $29 \%$. Thus, every $\$ 1,000$ increase in materials costs (such as added insulation) would amount to about $\$ 1,880$ in added cost to the customer. Program designers anticipated that a payment directly to the manufacturer would reduce the amount of added material costs that were marked up by both the manufacturer and retailer and, thus, leverage the financial effect of the payment.

The concept underlying the MAP payment is that it bridges the gap between what is cost-effective to a consumer and to the utility. Lee, Chin, and Onisko (1994) discuss this concept and its application in MAP. Prior to the program, energy consumption analyses relying on data from 150 demonstration homes projected that MAP homes with electric-resistance furnaces would each save an average of 6,700 kilowatt-hours $(\mathrm{kWh})$ per year compared with the typical homes being bought in the Pacific Northwest (Baylon and Davis 1993, p. 15). These savings estimates were used in negotiations among the utilities and home manufacturers as the basis for an agreement in which the utilities would pay the regional manufactured home plants (over 20 ) $\$ 2,500$ for each electrically heated home produced to MAP specifications.

Finally, MAP was intended to not only acquire conservation but also to induce market transformation. Program planners designed the program so that it would have a fundamental impact on the manufactured housing market and induce lasting conditions that would promote the construction and sale of energy-efficient homes.

When MAP was initiated in 1992, it was designed as a 4-year program to end in April 1996. The original agreement was based on the HUD-code energy-efficiency requirements in effect at the time, with a revision possible when the new HUD code came out. In October 1994, HUD implemented new, higher efficiency standards and the manufacturer payment was reduced to $\$ 1,500$.

All electrically heated manufactured homes produced in the region since October 1992 have been built to MAP specifications. As of mid-May 1995, over 50,000 MAP homes had been built, about 8,000 more than originally anticipated by utilities over the planned life of the program. In part because of its success and the unanticipated costs to the utilities, several utilities have initiated steps to withdraw from MAP prior to 
its planned end date. The lower-than-expected energy savings estimated by another impact evaluation conducted for several utilities also contributed to the utilities' decision to withdraw early from the program (RER 1994).

\subsection{EVALUATION PURPOSE AND OVERVIEW}

This evaluation has been conducted to determine what energy savings MAP has achieved, what the cost has been, and whether the program has been cost-effective. This evaluation focuses on the energy savings acquisition effects of the program, but it also discusses the very important market transformation implications of the program. Our examination of market transformation effects is limited; Bonneville is planning to conduct a thorough study of the market transformation aspect of the program.

MAP and its impacts need to be placed in the context of the activities that have occurred in the Pacific Northwest to improve the efficiency of manufactured homes. The projects and programs conducted since the early 1980s both increased the average efficiency level of manufactured homes and set the stage for MAP. Our evaluation does try to take into account the implications of these programs for MAP but the reader should be aware that MAP is only the latest in a series of programs and MAP cannot be analyzed in isolation. The costs of previous programs, their benefits, and their market transformation effects all influenced MAP. A comprehensive evaluation of the overall impacts of these programs should be conducted, but this effort was beyond the scope of our evaluation.

As this evaluation was being conducted, MAP was revised. When the new HUD code went into effect in October 1994, utilities decreased the amount of their payment to manufacturers. We distinguish between the two phases of the program, and refer to the program conditions in place before October 1994 as Phase 1 and from October 1994 through July 1995 (the probable end date of the program) as Phase 2.

The general approach we used in this impact evaluation was to analyze electric utility billing data for electrically heated manufactured homes and to compare the energy consumption of MAP and non-MAP homes. We interviewed occupants of each home by telephone to obtain information on factors, in addition to thermal efficiency, that might affect household utility bills. Manufacturers' data on the construction characteristics of the homes were collected also. We used three complementary methodologies to analyze the billing and other data with the intent of establishing reasonable bounds on the estimates of energy savings associated with MAP. 
In addition to our energy analysis, two other sources of energy savings estimates were available. Prior to the beginning of MAP, analysts conducted studies for Bonneville, using engineering analysis and metered data, to estimate energy savings and the levelized costs of energy-efficiency upgrades. These studies were available for comparison. As noted earlier, regional investor-owned utilities (IOUS) also conducted an energy analysis of MAP and non-MAP homes during late 1994, and these results also were available for comparison. The comparisons are discussed briefly in this report and in more detail in Lee et al. (1995).

We also obtained cost data readily available from previous Bonneville studies. We did not undertake an independent effort to collect primary cost data. We used the cost and energy data to examine the cost-effectiveness of MAP in terms of levelized costs of energy saved.

\subsection{SUMMARY FINDINGS}

The home owner interviews that we conducted and home characteristics data that we collected allow us to characterize differences and similarities between the baseline and MAP home samples (see Chapter 2). It is important to understand the characteristics of these two samples to identify any underlying differences that might affect the impact evaluation estimates, reveal any market trends, and identify possible program impacts beyond the basic energy consumption effects.

It is also important to recognize two facts about our baseline sample homes. First, their construction reflects regional energy-efficiency improvements that resulted from nearly a decade of conservation programs and projects. Second, they represent a lower bound on the actual average efficiency levels that consumers were purchasing prior to MAP. This is because we have excluded the energy-efficient homes built under the Super Good Cents (SGC) incentive and marketing program from our baseline homes sample.

The reader should be aware that the estimated MAP impacts presented here relative to our initial baseline sample homes are likely to understate the impacts relative to "true" control homes that did not benefit from 10 years of regional efficiency improvement programs. To derive program savings without including the influence of these prior programs, we calculate MAP savings and cost-effectiveness relative to a pre-program baseline home defined based on the best available information. 
Table 1.1 summarizes the geographic distribution of our baseline and MAP home samples. ${ }^{(a)}$ The results are presented by climate zone as defined by the Northwest Power Planning Council (1986) for its model conservation standards:

- Climate zone one has 4,000 to 6,000 heating-degree days (HDD)

- Climate zone two has 6,000 to 8,000 HDD

- Climate zone three has greater than 8,000 HDD

For simplicity, we refer to the three zones as $C Z 1, C Z 2$, and $C Z 3$.

TABLE 1.1. Manufactured Home Distribution by Climate Zone

\begin{tabular}{||l|c|c|c|c||}
\hline \multicolumn{2}{|c|}{ Sample } & CZ 1 & CZ 2 & CZ 3 \\
\hline \hline $\begin{array}{l}\text { Baseline } \\
\text { homes sample }\end{array}$ & $\begin{array}{c}\text { Number, } \\
\text { total=180 }\end{array}$ & 111 & 59 & 10 \\
\cline { 2 - 5 } & Share & $61.7 \%$ & $32.8 \%$ & $5.6 \%$ \\
\hline $\begin{array}{l}\text { MAP homes } \\
\text { sample }\end{array}$ & $\begin{array}{c}\text { Number, } \\
\text { total=167 }\end{array}$ & 79 & 62 & 26 \\
\cline { 2 - 5 } & Share & $47.3 \%$ & $37.1 \%$ & $15.6 \%$ \\
\hline Population & Share & $56.0 \%$ & $34.2 \%$ & $9.8 \%$ \\
\hline \hline $\begin{array}{l}\text { Note: Population estimates are based on Lee, Sandahl, and Kavanaugh } \\
\text { (1994) and Harkreader, Lee, and Sherman (1987). }\end{array}$ \\
\hline
\end{tabular}

As the table shows, the MAP home sample overrepresents $C Z 2$ and underrepresents $C Z 1$. We could identify no systematic explanation for this. In the baseline home sample, $C Z 3$ is underrepresented. This is because so many of the $C Z 3$ homes were built under the Super Good Cents energy-efficiency program or were heated with natural gas. These homes did not meet the criteria for our baseline sample and were

(a) All homes for which we had completed occupant surveys are included in the table. Energy analysis results are based on different subsets of these homes. 
excluded from our sample. The estimated population shares are used in our study to derive regional estimates.

Table 1.2 compares some of the key characteristics of homes in the two samples. Homes in the two samples differ very little in terms of average floor area, average window area, and percentage of heat pumps. Overall, a larger proportion of baseline homes are single section. In all climate zones, a larger share of baseline homes use some non-electric space heating. Air-conditioning (particularly room air conditioners) is more common in baseline homes. As expected, the average thermal conductance, $\mathrm{U}_{0}$, of baseline homes is significantly larger than it is for the MAP homes. Our data show that in 1992 the efficiency of non-MAP homes varies by climate zone, with substantially higher efficiency levels in $C Z 3$. This appears to be a relatively new phenomenon and may be an artifact of the sample and conditions just prior to MAP. Harkreader, Lee, and Sherman (1987) found no such geographic variations in 1986. The equivalent conductance attributable to infiltration is not included. The values for MAP homes are based on the MAP prescriptive specifications, not actual component R-value data, adjusted for estimated component areas.

Table 1.3 reports selected occupant survey responses. About a $50 \%$ larger share of MAP home buyers than baseline home buyers indicated that their home was special ordered, i.e., not off the lot. Nearly twice as large a share of MAP home buyers indicated that their energy bills were lower than expected. About $16 \%$ of occupants in both samples indicated that natural gas service was available at their homesite (but all homes in the samples use electricity for space and water heating). The mean incomes for both groups were about the same. Almost all the MAP home buyers were aware that their homes were built to special energy-efficiency requirements.

Table 1.4 compares the raw annual electricity billing data with the estimates from our final regression model for MAP Phase 1. The billing data are the mean values by climate zone for our baseline and MAP home samples. The regression estimates are from our final model calculated based on long-term weather. The estimates for preMAP baseline homes reflect our best estimate of the envelope thermal characteristics that would have been observed in the absence of major regional efficiency programs (see Section 3.4). Normalized energy consumption is calculated based on home floor area. The normalized values for the billing data are based on calculations for individual homes and the regression model estimates are calculated by dividing energy use by the typical floor area. 
TABLE 1.2. Characteristics of Homes in Samples

\begin{tabular}{||l|c|c|c|c|c|c|c|c||}
\hline \multirow{2}{*}{ Characteristic } & \multicolumn{2}{|c|}{ CZ 1 } & \multicolumn{2}{c|}{ CZ 2 } & \multicolumn{2}{c|}{ CZ 3 } & \multicolumn{2}{c||}{ Region } \\
\cline { 2 - 10 } & Baseline & MAP & Baseline & MAP & Baseline & MAP & Baseline & MAP \\
\hline \hline $\begin{array}{l}\text { Floor area, } \mathrm{tt}^{2} \\
\text { (mean) }\end{array}$ & 1,439 & 1,486 & 1,355 & 1,447 & 1,350 & 1,367 & 1,402 & 1,454 \\
\hline $\begin{array}{l}\text { Window area, } \\
\mathrm{ft}^{2} \text { (mean) }\end{array}$ & 153 & 168 & 158 & 172 & 147 & 142 & 154 & 169 \\
\hline \begin{tabular}{l} 
Heat pump \\
\hline Single-section
\end{tabular} & $17.1 \%$ & $7.8 \%$ & $18.5 \%$ & $13.1 \%$ & $22.2 \%$ & $38.1 \%$ & $18.1 \%$ & $12.6 \%$ \\
\hline $\begin{array}{l}\text { Some non- } \\
\text { electric } \\
\text { heating used }\end{array}$ & $23.4 \%$ & $11.4 \%$ & $25.4 \%$ & $21.0 \%$ & $40.0 \%$ & $3.9 \%$ & $25.7 \%$ & $13.9 \%$ \\
\hline $\begin{array}{l}\text { Air } \\
\text { conditioning }\end{array}$ & $42.3 \%$ & $30.3 \%$ & $47.5 \%$ & $30.7 \%$ & $22.2 \%$ & $15.4 \%$ & $42.1 \%$ & $29.0 \%$ \\
\hline $\begin{array}{l}\text { Average U- } \\
\text { value } \\
\text { (conductive), } \\
\text { Btu/hr- }{ }^{\circ} \mathrm{F}-\mathrm{ft}^{2}\end{array}$ & 0.101 & 0.050 & 0.093 & 0.051 & 0.078 & 0.051 & 0.096 & 0.050 \\
\hline
\end{tabular}

TABLE 1.3. Occupant Survey Responses

\begin{tabular}{||l|c|c|}
\hline \multicolumn{1}{|c|}{ Response } & Baseline homes & MAP homes \\
\hline \hline Special-ordered home & $55 \%$ & $82 \%$ \\
\hline Aware home was built to high efficiency requirements & NA & $91 \%$ \\
\hline Energy bills lower than expected & $22 \%$ & $42 \%$ \\
\hline Natural gas available at homesite & $17 \%$ & $15 \%$ \\
\hline Median annual family income & $\$ 30,300$ & $\$ 29,100$ \\
\hline
\end{tabular}

Table 1.5 summarizes our energy savings estimates. These estimates only include direct energy savings for homes acquired under MAP; they do not include any market transformation effects attributable to the program. They are produced from our regression analysis, the most comprehensive approach we used in this study, and 
TABLE 1.4. Mean Annual Electricity Consumption Estimates

\begin{tabular}{|c|c|c|c|c|c|}
\hline \multirow{2}{*}{\multicolumn{2}{|c|}{$\begin{array}{l}\text { Climate } \\
\text { zone }\end{array}$}} & \multicolumn{2}{|c|}{ Raw billing data means ${ }^{(0)}$} & \multicolumn{2}{|c|}{ Regression estimates $^{(b)}$} \\
\hline & & $\begin{array}{l}\text { Baseline } \\
\text { sample }\end{array}$ & MAP sample & Pre-MAP baseline ${ }^{(\epsilon)}$ & MAP, Phase 1 \\
\hline 1 & & $\begin{array}{c}16,800 \mathrm{kWh} \\
12.3 \mathrm{kWh} / \mathrm{tt}^{2}\end{array}$ & $\begin{array}{l}14,500 \mathrm{kWh} \\
9.85 \mathrm{kWh} / \mathrm{ft}^{2}\end{array}$ & $\begin{array}{c}17,201 \mathrm{kWh} \\
11.7 \mathrm{kWh} / \mathrm{ft}^{2}\end{array}$ & $\begin{array}{c}14,138 \mathrm{kWh} \\
9.62 \mathrm{kWh} / \mathrm{ft}^{2} \\
\end{array}$ \\
\hline 2 & & $\begin{array}{c}18,500 \mathrm{kWh} \\
14.4 \mathrm{kWh} / \mathrm{tt}^{2}\end{array}$ & $\begin{array}{c}17,100 \mathrm{kWh} \\
12.0 \mathrm{kWh} / \mathrm{tt}^{2}\end{array}$ & $\begin{array}{l}21,450 \mathrm{kWh} \\
14.6 \mathrm{kWh} / \mathrm{tt}^{2} \\
\end{array}$ & $\begin{array}{c}16,950 \mathrm{kWh} \\
11.5 \mathrm{kWh} / \mathrm{ft}^{2}\end{array}$ \\
\hline 3 & & $\begin{array}{c}19,300 \mathrm{kWh} \\
15.0 \mathrm{kWh} / \mathrm{tt}^{2}\end{array}$ & $\begin{array}{c}19,100 \mathrm{kWh} \\
15.0 \mathrm{kWh} / \mathrm{ft}^{2}\end{array}$ & $\begin{array}{c}24,530 \mathrm{kWh} \\
16.7 \mathrm{kWh} / \mathrm{ft}^{2}\end{array}$ & $\begin{array}{c}18,810 \mathrm{kWh} \\
12.8 \mathrm{kWh} / \mathrm{ft}^{2} \\
\end{array}$ \\
\hline Region ${ }^{(d)}$ & & $\begin{array}{c}17,600 \mathrm{kWh} \\
13.3 \mathrm{kWh} / \mathrm{ft}^{2}\end{array}$ & $\begin{array}{c}15,800 \mathrm{kWh} \\
11.1 \mathrm{kWh} / \mathrm{ft}^{2}\end{array}$ & $\begin{array}{c}19,340 \mathrm{kWh} \\
13.2 \mathrm{kWh} / \mathrm{ft}^{2}\end{array}$ & $\begin{array}{c}15,550 \mathrm{kWh} \\
10.6 \mathrm{kWh} / \mathrm{ft}^{2}\end{array}$ \\
\hline (1) & \multicolumn{5}{|c|}{$\begin{array}{l}\text { The consumption data are for the most recent year for each home. Normalized } \\
\text { values are the mean consumption per square foot of floor area. } \\
\text { Estimates are for typical occupant demographics and homes with typical } \\
\text { dimensions, appliance stocks, and mix of electric and backup heating systems. } \\
\text { Consumption is calculated based on long-term average weather. Normalized } \\
\text { values are the mean consumption divided by the mean square feet of floor. area. } \\
\text { Pre-MAP baseline estimates are based on a home with the envelope thermal } \\
\text { conductance anticipated if no significant regional conservation programs had } \\
\text { occurred. The assumed } U_{0}=0.098 \text { across all climate zones. } \\
\text { Regional estimates are weighted averages based on PNL population distribution } \\
\text { estimates in Table 1.1. }\end{array}$} \\
\hline
\end{tabular}

reflect standardized assumptions. Table 1.5 presents two savings estimates for Phases 1 and 2 and the overall program. The "All heating types" estimates reflect the mix of heating equipment observed in our entire sample of homes. These savings are adjusted based on the proportions of homes that have backup wood heat, heat pumps, and other systems in addition to electric resistance furnaces. These estimates are intended to capture the net electricity consumption effects on the Bonneville system. The "electric resistance heating" estimates are calculated assuming that all heat is provided by electric resistance furnaces. These estimates are intended to capture total energy resource effects (including reduced use of wood and other energy sources) for the entire regional energy system. The standardized assumptions are used to net out the effects of house size, number of occupants, use of non-electric heat, etc., to provide directly comparable energy consumption estimates and savings. 
TABLE 1.5. MAP Acquisition Energy Savings, kWh/year/home

\begin{tabular}{|c|c|c|c|c|}
\hline \multirow{2}{*}{$\begin{array}{l}\text { Climate } \\
\text { zone }\end{array}$} & \multicolumn{2}{|c|}{ Phase 1} & \multicolumn{2}{|c|}{ Phase 2} \\
\hline & $\begin{array}{l}\text { All heating } \\
\text { types }\end{array}$ & $\begin{array}{l}\text { Electric } \\
\text { resistance } \\
\text { heating }\end{array}$ & $\begin{array}{l}\text { All heating } \\
\text { types }\end{array}$ & $\begin{array}{c}\text { Electric } \\
\text { resistance } \\
\text { heating }\end{array}$ \\
\hline 1 & $\begin{array}{c}3,063 \\
( \pm 600) \\
2.08 \mathrm{kWh} / \mathrm{ft}^{2}\end{array}$ & $\begin{array}{c}3,961 \\
( \pm 700) \\
2.69 \mathrm{kWh} / \mathrm{ft}^{2}\end{array}$ & $\begin{array}{c}2,029 \\
( \pm 690) \\
1.38 \mathrm{kWh} / \mathrm{ft}^{2}\end{array}$ & $\begin{array}{c}2,524 \\
( \pm 780) \\
1.72 \mathrm{kWh} / \mathrm{ft}^{2}\end{array}$ \\
\hline 2 & $\begin{array}{c}4,497 \\
( \pm 900) \\
3.06 \mathrm{kWh} / \mathrm{ft}^{2}\end{array}$ & $\begin{array}{c}5,526 \\
( \pm 980) \\
3.76 \mathrm{kWh} / \mathrm{ft}^{2}\end{array}$ & $\begin{array}{c}2,936 \\
( \pm 1,000) \\
2.00 \mathrm{kWh} / \mathrm{tt}^{2}\end{array}$ & $\begin{array}{c}3,522 \\
( \pm 1,090) \\
2.40 \mathrm{kWh} / \mathrm{ft}^{2}\end{array}$ \\
\hline 3 & $\begin{array}{c}5,719 \\
( \pm 1,080) \\
3.89 \mathrm{kWh} / \mathrm{ft}^{2}\end{array}$ & $\begin{array}{c}6,300 \\
( \pm 1,110) \\
4.29 \mathrm{kWh} / \mathrm{ft}^{2}\end{array}$ & $\begin{array}{c}3,672 \\
( \pm 1,200) \\
2.50 \mathrm{kWh} / \mathrm{ft}^{2}\end{array}$ & $\begin{array}{c}4,015 \\
( \pm 1,240) \\
2.73 \mathrm{kWh} / \mathrm{ft}^{2}\end{array}$ \\
\hline Region & $\begin{array}{c}3,814 \\
( \pm 470) \\
2.59 \mathrm{kWh} / \mathrm{ft}^{2}\end{array}$ & $\begin{array}{c}4,725 \\
( \pm 530) \\
3.21 \mathrm{kWh} / \mathrm{ft}^{2}\end{array}$ & $\begin{array}{c}2,500 \\
( \pm 530) \\
1.70 \mathrm{kWh} / \mathrm{ft}^{2}\end{array}$ & $\begin{array}{c}3,012 \\
( \pm 580) \\
2.05 \mathrm{kWh} / \mathrm{ft}^{2}\end{array}$ \\
\hline \multicolumn{5}{|c|}{$\begin{array}{l}\text { Notes: Numbers in parentheses indicate an approximate } 95 \% \text { confidence interval } \\
\text { based on the regression analysis coefficients. See Lee et al. (1995) for a } \\
\text { discussion of the calculation. Normalized savings are based on the typical floor } \\
\text { area used in our analysis. }\end{array}$} \\
\hline
\end{tabular}

Table 1.6 presents summary levelized cost results based on the energy savings shown in Table 1.5. Bonneville does not define a Bonneville system perspective levelized cost threshold, but we use Bonneville's conservation programs' average target of $2.46 / \mathrm{kWh}$ as the cost-effectiveness test. From the Bonneville system perspective, both phases of MAP are cost-effective in CZs 2 and 3 . In CZ 1, Phase 1 exceeds the Bonneville system perspective cost-effectiveness level slightly, but Phase 2 is marginally costeffective. Averaged over the region, each phase is cost-effective, as are both phases combined.

From the regional system perspective (including customer and utility cost, and accounting for all energy savings in MAP homes), MAP's levelized cost is far below the cost-effectiveness threshold of $4.3 \% / \mathrm{kWh}$. Regionally, MAP's levelized acquisition cost during Phase 1 is $62 \%$ below the cost-effectiveness threshold and during Phase 2 it is 
$60 \%$ below the threshold. For both phases combined, the acquisition levelized cost is $61 \%$ below the threshold.

Taking the market transformation impacts of MAP into account improves the costeffectiveness. Evidence indicates that sales of MAP homes will continue after MAP ends. For the utility, there are no costs associated with these homes, but the energy savings that result from these "free drivers" reduce the load requirements on the utility. From the Bonneville system perspective, these market transformation effects may reduce program levelized costs as much as $40 \%$.

TABLE 1.6. MAP Acquisition Levelized Costs, $\$ / k W h ~(1993 \$)$

\begin{tabular}{||l|c|c|c|c|c|c||}
\hline \hline \multirow{2}{*}{$\begin{array}{l}\text { Climate } \\
\text { zone }\end{array}$} & \multicolumn{2}{|c|}{ Phase 1 } & \multicolumn{2}{c|}{ Phase 2 } & \multicolumn{2}{c|}{ Overall program } \\
\cline { 2 - 7 } & $\begin{array}{c}\text { Bonneville } \\
\text { system }\end{array}$ & $\begin{array}{c}\text { Regional } \\
\text { system }\end{array}$ & $\begin{array}{c}\text { Bonneville } \\
\text { system }\end{array}$ & $\begin{array}{c}\text { Regional } \\
\text { system }\end{array}$ & $\begin{array}{c}\text { Bonneville } \\
\text { system }\end{array}$ & $\begin{array}{c}\text { Regional } \\
\text { system }\end{array}$ \\
\hline \hline 1 & 2.81 & 2.11 & 2.36 & 2.37 & 2.73 & 2.15 \\
\hline 2 & 1.64 & 1.27 & 1.37 & 1.46 & 1.59 & 1.30 \\
\hline 3 & 1.11 & 1.01 & 0.92 & 1.18 & 1.08 & 1.04 \\
\hline Region & 2.09 & 1.63 & 1.75 & 1.85 & 2.03 & 1.67 \\
\hline \hline $\begin{array}{l}\text { Note: The assumed cost-effective level for the Bonneville system cost test is 2.46/kWh. } \\
\text { Bonneville's cost-effective level for the regional system cost test is 4.34/kWh. }\end{array}$ \\
\hline
\end{tabular}




\subsection{SAMPLE DESIGN AND DATA COLLECTION}

This chapter presents an overview of the sample design and the data collection process used in this evaluation. A more complete description is presented in Sandahl, Lee, and Chin (1995).

\subsection{SAMPLE DESIGN}

To compare the electric energy use of manufactured homes constructed to the MAP specifications with the energy use of a baseline group of manufactured homes, samples of homes and their occupants were needed from both groups. Definitions of the MAP and baseline homes used for this study are as follows:

- MAP homes - Electrically heated manufactured homes built in the Northwest after April 1, 1992, and constructed to the energy-efficiency guidelines specified in the MAP contract.

- Baseline homes - Electrically heated, non-Super Good Cents manufactured homes built in the Northwest during January, February, or March 1992.

Data on MAP homes, including the original home owner, were available from the MAP database provided by Bonneville. In addition, regional state energy offices had contacted a number of MAP home owners in a related study. No such database or prior study results, however, were available to provide information on baseline homes and their owners.

A minimum of 150 MAP home owner interviews, complemented with detailed energyrelated data on the home, was the target for this evaluation. ${ }^{(s)}$ The MAP data collection effort relied on two sources of information: 1) MAP home and home owner data collected as part of a study of MAP homes conducted by regional state energy offices and 2) information contained in Bonneville's database of MAP homes.

(a) Final sample sizes of 150 MAP and 150 baseline homes were targeted based on the budget constraint and energy consumption estimates from Baylon et al. (1991) and Baylon and Davis (1993). Data from these reports suggested that climate zone 2 energy savings of about 7,700 kWh could be expected from MAP. We used this estimate, and estimates of total electricity consumption and standard deviations, to determine that a $95 \%$ confidence interval for our 150 home samples would be energy savings of 6,400 to $9,000 \mathrm{kWh}$. 
The identification of a "suitable" control group was discussed at length by PNL and Bonneville staff during evaluation planning. To reflect energy-efficiency improvement trends in the industry (including new appliance standards), limit data collection costs, and facilitate data collection, PNL chose to use homes constructed during the three months before the start of MAP.

Bonneville's manufactured home energy efficiency programs in effect since the early 1980 s undoubtedly increased the efficiency of typical manufactured homes sold in the region, including those in our baseline home sample. As a result, the baseline energy consumption of the 1992-vintage "baseline" homes may be less than would have been found if we could have identified a "true" control group of homes that had been unaffected by any of the regional efficiency programs. Consequently, the energy savings implied by a simple comparison of MAP homes with our baseline homes is likely to understate the savings impacts of MAP alone.

As with the MAP homes, a minimum of 150 baseline home owner interviews, complemented with detailed energy-related data on the home, were targeted for this evaluation. Prior to the MAP, there was no comprehensive database available containing home and owner information. Two approaches were taken to develop a sample of baseline homes: an initial random sample of $\mathbf{4 5 0}$ homes drawn'from a data set available from the National Conference of States on Building Codes and Standards (NCSBCS) and a request to regional manufacturers for data on $\mathbf{3 0 0}$ additional homes.

Surprisingly, over $60 \%$ of the randomly selected baseline homes identified to the manufacturers turned out to be Super Good Cents homes, far higher than available SGC penetration estimates indicated. These and the gas-heated homes were not usable for our evaluation.

Both sampling approaches relied heavily on the cooperation of regional manufacturers to provide the needed data, and cooperation was very good. All but one regional manufacturer provided the critically needed information.

\subsection{DATA COLLECTION}

A telephone survey was used to collect home and owner information for both the MAP and baseline homes. Separate, but similar, MAP and baseline home questionnaires were developed by PNL based on the needs of the impact evaluation. Questions related to the characteristics of the home and characteristics and behavior of the 
owner. Questionnaires were reviewed by Bonneville and the MAP evaluation Technical Advisory Group prior to the survey pretest.

MAP and baseline home owners were contacted via phone and interviewed, if willing to participate in the study. Interviews lasted about $\mathbf{3 0}$ minutes. After completing the interview, respondents were asked if they would be willing to sign and return a form that would allow the utility to provide PNL with billing data on their home.

In all, 167 MAP interviews were completed; most of the respondents participated in both this impact evaluation and the state study. Signed utility release forms were available for 134 of the 167 MAP respondents. For the baseline homes, 183 interviews were completed and we obtained signed utility billing release forms from 123 respondents. 


$$
2.4
$$




\subsection{OVERVIEW OF ANALYSES}

This chapter discusses briefly the analyses used in this impact evaluation. It provides an overview of the three energy analysis approaches, the energy savings analysis, and the cost-effectiveness analysis. It also discusses some of the methodological issues that influenced the analyses. The supplemental technical appendix (Lee et al. 1995) provides more detail on the analyses.

\subsection{TIERED ANALYSIS APPROACH: BILLING DATA AND PRISM ANALYSES RESULTS}

A three-tiered process was used to analyze the energy consumption of both MAP and baseline homes. We used multiple approaches to enhance the validity of the estimates, to compare the results from different methodologies, and to gain insights into the factors related to energy consumption. The approaches were selected to take advantage of the whole-house electric billing data available on each home.

The first-tier approach was a simple comparison of annual billing data. We analyzed those homes in our sample for which at least 12 months of billing data were available. We calculated the mean annual kWh consumption for MAP homes and baseline homes in each of the three MCS climate zones (defined in Chapter 1). We used the means for the two home samples to estimate the net energy savings. Next, we conducted a simple regression analysis to adjust the billing data to reflect the effect of significant characteristics of the homes, such as envelope area. No adjustments were made for long-term weather. These regressions were used to estimate adjusted annual electricity consumption and estimate savings for MAP homes.

Table 3.1 summarizes the billing data results. The data show that the total consumption of both MAP and baseline homes is higher in the colder climate zones, as expected. Also as expected, the total consumption of MAP homes is less than baseline homes in each climate zone. ${ }^{\text {(a) }}$

The row labeled "Savings, unadjusted" shows the differences between the mean billing data estimates for the two samples. This simple comparison of billing data alone

(a) The small size of the CZ 3 baseline homes sample and standard errors associated with the estimates make these estimates unreliable. 
suggests that, while MAP homes consume less electricity than the baseline homes in our study, the apparent savings are only about $26 \%$ of the pre-program estimates.

TABLE 3.1. Simplified Billing Data Analysis Results

\begin{tabular}{|c|c|c|c|c|}
\hline & $C Z 1$ & CZ 2 & $\mathrm{CZ} 3$ & Region \\
\hline & kWh & $k W h$ & $k W h$ & kWh \\
\hline $\begin{array}{l}\text { Baseline homes, mean annual } \\
\text { kWh consumption }\end{array}$ & $\begin{array}{l}16,800 \\
(580)^{(0)} \\
(77)^{(0)}\end{array}$ & $\begin{array}{c}18,500 \\
(1,030)^{(a)} \\
(37)^{(0)}\end{array}$ & $\begin{array}{c}19,300 \\
(3,520)^{(0)} \\
(5)^{(b)}\end{array}$ & $\begin{array}{l}17,600 \\
(590)^{(0)} \\
(119)^{(b)}\end{array}$ \\
\hline $\begin{array}{l}\text { MAP homes, mean annual } \\
\text { kWh consumption }\end{array}$ & $\begin{array}{l}14,500 \\
(569)^{(0)} \\
(59)^{(b)}\end{array}$ & $\begin{array}{l}17,100 \\
(839)^{(6)} \\
(55)^{(0)}\end{array}$ & $\begin{array}{c}19,100 \\
(1,150)^{(0)} \\
(20)^{(0)}\end{array}$ & $\begin{array}{l}15,800 \\
(443)^{(0)} \\
(134)^{(b)}\end{array}$ \\
\hline Savings, unadjusted & $\begin{array}{l}2,300 \\
(812)^{(0)}\end{array}$ & $\begin{array}{c}1,400 \\
(1,330)^{(0)}\end{array}$ & $\begin{array}{c}200 \\
(3,700)^{(0)}\end{array}$ & $\begin{array}{l}1,800 \\
(738)^{(0)}\end{array}$ \\
\hline Savings, adjusted & $\begin{array}{c}3,420 \\
(4.20)^{(c)}\end{array}$ & $\begin{array}{c}2,900 \\
(2.66)^{(6)}\end{array}$ & $\begin{array}{c}5,270 \\
(2.17)^{(6)}\end{array}$ & 3,420 \\
\hline \multicolumn{5}{|c|}{$\begin{array}{l}\text { (a) Standard error of the sample mean } \\
\text { (b) Sample size } \\
\text { (c) t-statistic for MAP coefficient in regression }\end{array}$} \\
\hline
\end{tabular}

Because this simple billing data comparison controls for none of the differences between the MAP and baseline sample homes, we conducted a simplified regression analysis to develop adjusted savings estimates. We derived simplified regression equations for each climate zone based on predictor variables including shell area, percent of heat supplied by non-electric fuel, presence of a heat pump, presence of air-conditioning, whether the home was a single- or multi-section home, and whether the home was a MAP or baseline home. In all cases, the dummy variable used to capture the effect of MAP was significant at the $8 \%$ level or better. Table 3.1 presents the coefficient associated with MAP in these simple regressions as "Savings, adjusted."

For the region, the adjusted savings are almost twice as large as the unadjusted values from the billing data and $51 \%$ of the pre-program estimated savings. Several factors contribute to the difference. First, non-electric supplemental heating is more common in our sample of baseline homes than in the MAP homes. Controlling for the use of non-electric heat increases the estimated energy savings substantially, 
particularly in $\mathrm{CZ} 3^{\left({ }^{(a)}\right.}$ Second, in zone 1 heat pumps are more common in our baseline homes and they tend to reduce energy consumption. Third, our sample baseline homes are smaller than MAP homes on the average, and this tends to reduce electricity use differences between MAP and baseline homes.

This first-tier analysis was limited to actual-year billing data and made no attempt to examine separately space conditioning and other temperature-sensitive end uses. No adjustments were made to normalize the effect of weather. These effects were addressed partially in the second-tier analysis.

The second-tier approach was application of the PRInceton Scorekeeping Method (PRISM). ${ }^{\text {(b) }}$ This methodology uses monthly billing data to estimate coefficients that can be used to predict the non-temperature- and temperature-sensitive portions of energy consumption. We used PRISM to estimate electricity consumption for a "normal" weather year for MAP and baseline homes, and then used the difference between these standardized estimates to estimate energy savings by climate zone.

Results reported here are based on the original Heating-Only (HO) PRISM model, which was developed at the Princeton Center for Energy Studies. It disaggregates a customer's annual energy use into two weather-normalized primary components: space heating and total load. ${ }^{(c)}$ The PRISM results reported here are annual consumptions normalized to 30-year long-term weather data.

Table 3.2 summarizes the means of the unfiltered PRISM results, i.e., for all homes for which PRISM converges on a balance temperature, regardless of the goodness of the PRISM fit. In all cases, the total consumption exceeds the raw billing data means (Table 3.1), probably because the PRISM results are extrapolated to long-term weather

(a) Although use of non-electric heat was more common in baseline homes than in MAP homes, there was no consistent evidence that MAP induced home owners to use less non-electric heat. In this time period, however, differences in nonelectric heat use significantly affected the apparent savings of MAP homes.

(b) The authors would like to thank Margaret Fels for making available the PRISM models used in this study. PRISM is described in Fels, Reynolds, and Stram (1986).

(c) The PRISM "heating" consumption estimates are more properly considered to be the consumption component that is sensitive to heating-degree days. We report our estimates as "heating" consumption estimates, but the reader should be aware that this PRISM output can capture other temperature-sensitive electricity consumption. Notable end-uses that may be partially reflected in the "heating" consumption include water heating and lighting. 
conditions, which are colder than the period for which we collected billing data. Note that the base load is calculated as the difference between the estimated total and "heating" consumption, and the base load means vary $25 \%$ (2,075 kWh) between the lowest and highest estimates. It is unlikely that the base loads actually vary this much, raising doubts about the accuracy of the "heating" estimates from which they are derived. CZ 3 results are questionable because of the small sample sizes.

The estimated savings presented in Table 3.2 are based on differences between the "heating" estimates from PRISM, rather than the estimated total consumption, because MAP is intended to reduce space heating usage. Because of the unlikely variability observed in the base load estimates, the savings estimates based on these PRISM results are not very reliable. In addition, the standard errors of the estimated savings are very large, indicating that this approach does not produce very reliable results.

TABLE 3.2. PRISM Results, Unfiltered Data

\begin{tabular}{|c|c|c|c|}
\hline & CZ 1 & CZ 2 & CZ 3 \\
\hline & $k W h$ & kWh & $k W h$ \\
\hline $\begin{array}{l}\text { Baseline homes } \\
\text { "Heating" use } \\
\text { Base load use } \\
\text { Total } \\
\text { Sample size }\end{array}$ & $\begin{array}{c}9,710(1,600) \\
9,004(1,609) \\
18,714(165) \\
63\end{array}$ & $\begin{array}{c}9,789(3,350) \\
10,214(3,358) \\
20,003(231) \\
32\end{array}$ & $\begin{array}{c}10,771(1,082) \\
9,198(1,150) \\
19,969(390) \\
6\end{array}$ \\
\hline $\begin{array}{l}\text { MAP homes, billing data } \\
\text { "Heating" use } \\
\text { Base load use } \\
\text { Total } \\
\text { Sample size }\end{array}$ & $\begin{array}{c}7,417(9,372) \\
8,139(9,373) \\
15,611(160) \\
59\end{array}$ & $\begin{array}{c}8,159(2,524) \\
9,805(2,531) \\
17,965(187) \\
48\end{array}$ & $\begin{array}{c}9,652(912) \\
9,611(942) \\
19,262(235) \\
18\end{array}$ \\
\hline $\begin{array}{l}\text { Savings (baseline "heating" } \\
\text { minus MAP "heating") }\end{array}$ & $\begin{array}{c}2,293 \\
(9,507)\end{array}$ & $\begin{array}{c}1,630 \\
(4,194)\end{array}$ & $\begin{array}{c}1,119 \\
(1,415)\end{array}$ \\
\hline
\end{tabular}

To reduce the error in the PRISM estimates and to focus specifically on homes with electric heating only, we present results for a filtered sample of homes in Table 3.3. 
These results exclude homes that 1) PRISM does not model well, 2) use non-electric backup heat, or 3) have an air-conditioning load. This filtering removes homes that have loads that do not follow the simple relationship to weather assumed by PRISM.

Filtering the observations reduces the standard errors of the estimates considerably, particularly in $C Z 1$. The variation in base load consumption estimates decreases, primarily within a climate zone. Significant differences in base load estimates across climate zones still exist, however. The savings estimates exhibit the expected behavior of increasing in the colder climate zones. No consistent relationship occurs between these results and the raw billing data results presented in Table 3.1. The savings estimates in Table 3.3, however, are consistently less than the adjusted billing data estimates presented in Table 3.1.

TABLE 3.3. PRISM Results, Filtered Data

\begin{tabular}{|c|c|c|c|}
\hline & CZ 1 & $\mathrm{CZ} 2$ & $C Z 3$ \\
\hline & kWh & kWh & kWh \\
\hline $\begin{array}{l}\text { Baseline homes } \\
\text { "Heating" use } \\
\text { Base load use } \\
\text { Total } \\
\text { Sample size }\end{array}$ & $\begin{array}{r}9,617(981) \\
8,519(991) \\
18,136(142) \\
39\end{array}$ & $\begin{array}{r}11,090(663) \\
9,820(696) \\
20,910(212) \\
17\end{array}$ & $\begin{array}{c}13,502(1,377) \\
9,666(1,464) \\
23,168(498) \\
4\end{array}$ \\
\hline $\begin{array}{l}\text { MAP homes, billing data } \\
\text { "Heating" use } \\
\text { Base load use } \\
\text { Total } \\
\text { Sample size }\end{array}$ & $\begin{array}{r}8,190(969) \\
8,008(990) \\
16,198(204) \\
34\end{array}$ & $\begin{array}{c}9,103(842) \\
9,888(864) \\
18,992(193) \\
30\end{array}$ & $\begin{array}{c}9,656(961) \\
8,961(992) \\
18,617(245) \\
14\end{array}$ \\
\hline $\begin{array}{l}\text { Savings (baseline "heating" - } \\
\text { MAP "heating") }\end{array}$ & $\begin{array}{c}1,427 \\
(1,379)\end{array}$ & $\begin{array}{c}1,987 \\
(1,072)\end{array}$ & $\begin{array}{c}3,846 \\
(1,679)\end{array}$ \\
\hline
\end{tabular}

The first and second tier analyses provide useful findings including the following:

- Differences in the characteristics of MAP and baseline homes, such as floor area, need to be taken into account in the analysis and the analysis should be based on standardized home characteristics.

- The analysis should reflect long-term weather conditions. 
- Non-electric heating usage can affect the results significantly and should be included in the analysis.

The next section discusses our final analysis, which takes into account these findings, and is the basis for our energy savings estimates.

\subsection{THIRD TIER ANALYSIS: REGRESSION ANALYSIS}

The third tier approach used regression analysis to analyze monthly energy consumption, taking into account significant factors, including home and occupant characteristics, likely to influence electricity usage. This analysis provided a much better understanding of what affected energy consumption and allowed us to account for more factors. We used the regression results to estimate energy consumption under "normal" weather conditions for each climate zone and to estimate energy savings associated with MAP.

We applied this approach to all sample homes for which we obtained any billing data. Our general approach was to develop a model of total electric consumption that utilizes available information about the home in concert with known or anticipated thermal-physical relationships. The anticipated thermal-physical relationships include these:

- heating load response to outdoor temperature:(a) This effect is expected to be influenced by a home's thermal integrity (the primary effect of MAP), size, and perhaps configuration (e.g., number of sections).

- cooling load response to outdoor temperature(e)

- water heating load response to outdoor temperature: Many other end uses interact with the water heating load (dishwashers, hot tubs, etc.).

- $\quad$ seasonal variation of various miscellaneous loads (E.g., lighting is expected to increase when days are shorter.)

- response of various loads to the number of occupants.

(a) Both heating and cooling are also functions of other influences, notably solar heat gains. Unfortunately, lack of solar data from most homes' locations prevents direct modeling of these effects. 
The survey data allow us to include the effects of occupant and home characteristics on many of these relationships.

The model we use is similar to a conditional demand analysis in that it utilizes appliance inventories to explain total $\mathrm{kWh}$ consumption, but is formulated around the anticipated thermal-physical relationships. Because differences in heating (and maybe cooling) performance are the primary anticipated effect of MAP, we focus on those terms in formulating the model. The final model is shown in Equation 3.1. The terms are defined in Table 3.4 and the values of the coefficients are shown in Table 3.5. The adjusted $R$-squared value for the regression is 0.60 . The residual standard error of the regression is 10.9 on 2,722 degrees of freedom.

The model has the characteristics of a statistically-adjusted engineering model, albeit with a very simple engineering model. The building thermal conductance (UA) used in the regression is based on manufacturers' data on home components for the baseline homes and on knowledge of MAP design requirements for the MAP homes. The UA includes infiltration effects estimated from an air exchange rate of 0.35 air changes per hour $(\mathrm{ACH})$ assumed for all homes. The coefficient for the heating equipment terms adjusts the anticipated HDD slope to match the data. If Equation 3.1 were to model the heating response perfectly, the expected value of the coefficient would"be unity. We expect the coefficient to be less than 1.0, however, because most homes have lower balance temperatures than the 65 degrees used to calculate HDD. The heating equipment terms are separated so that the effect for MAP homes is measured relative to the effect for all homes, assuming that the null hypothesis is that energy consumption in all homes has the same dependence on HDD and UA. Baseline home energy use is calculated by using the non-MAP coefficients only; MAP home usage is calculated by combining the non-MAP and MAP coefficients.

Because many of the appliance and equipment end uses respond to climate variations or vary seasonally, we adjust them (see Lee et al. 1995) to account for their expected seasonal variations. We use data from the Bonneville Power Administration's Regional End-Use Metering Project (REMP) to supply these adjustments (Cahill, Ritland, and Lin-Kelly 1992).

\subsection{ENERGY SAVINGS ANALYSIS}

We use the third-tier (regression) analysis results to estimate energy savings. Estimating energy savings involves consideration of several important factors. 


$$
\begin{aligned}
& \frac{k W h}{N_{\text {days }}}=\text { Intercept } \\
& +\alpha_{1} \text { Incomelow } \\
& +\alpha_{2} \text { IncomeHigh } \\
& +\alpha_{3} / \text { sOccDaytime } \\
& +\alpha_{4} N_{\text {waterbeds }} \\
& +\alpha_{5} N_{\text {compution }} \\
& +\alpha_{6} N_{\text {netrigerators }} \times A l l o C_{\text {retrigerator }} \\
& +\alpha_{7} N_{\text {troezers }} \times A l l o c_{\text {frower }} \\
& +\alpha_{g} \log \left(N_{\text {occ }}+1\right) \times N_{\text {septic pumps }} \\
& +\alpha_{g} \log \left(N_{\infty \infty}+1\right) \times N_{\text {woll pumpos }} \\
& +\alpha_{10} \log \left(N_{o c c}+1\right) \times N_{\text {dichwachers }} \times A / l o c_{\text {divermasther }}
\end{aligned}
$$

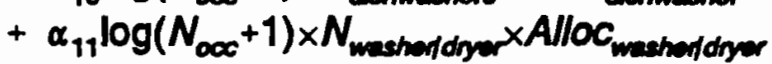

$$
\begin{aligned}
& +\alpha_{12} \log \left(N_{\text {occ }}+1\right) \times N_{\text {water hodtor }} \times A l l o C_{\text {water houter }} \\
& +\alpha_{13} \text { lsZone1 } \times \text { HasAC } C D D Y N_{\text {dese }} \\
& +\alpha_{14} H a s A C \times C D D I N_{\text {dare }} \\
& +\alpha_{15} \text { HasElecOnls } \times / \text { MAP } \times \text { C } U A \times\left(\frac{H D D}{N_{\text {days }}}\right) \\
& +\alpha_{16} \text { HasElec\& Wood } / \text { IsMAP } \times \text { C UAx }\left(\frac{H D D}{N_{\text {deyse }}}\right) \\
& +\alpha_{17} \text { HasElec\& Other } \times I s M A P \times C \times U A \times\left(\frac{H D D}{N_{\text {days }}}\right) \\
& +\alpha_{18} \text { HasElecOnly } \times C \times U A \times\left(\frac{H D D}{N_{\text {degs }}}\right) \\
& +\alpha_{19} \text { HasElec\& Wood } \times C \times U A \times\left(\frac{H D D}{N_{\text {degs }}}\right) \\
& +\alpha_{20} \text { HasEleck Other } C \times \cup A \times\left(\frac{H D D}{N_{\text {deys }}}\right) \\
& +\alpha_{21} \text { HasHPonly } \times / S M A P_{\times} C_{\times} U A \times\left(\frac{H D D}{N_{\text {dass }}}\right) \\
& +\alpha_{22} H a s H P \& W o o d \times / S M A P \times C \times U A \times\left(\frac{H D D}{N_{\text {degs }}}\right) \\
& +\alpha_{23} \text { HasHPonlyx } C \times U A \times\left(\frac{H D D}{N_{\text {degs }}}\right) \\
& +\alpha_{24} \text { HasHP\&Wood } \times C \times U A \times\left(\frac{H D D}{N_{\text {dey }}}\right) \\
& +\alpha_{25} / \text { sVacant }
\end{aligned}
$$


TABLE 3.4. Definition of Terms in Equation 3.1

\begin{tabular}{|c|c|}
\hline Term & Definition \\
\hline kWh & Total electricity use in the billing period \\
\hline Intercept & The regression intercept term \\
\hline$N_{\text {dars }}$ & Number of days in the billing period \\
\hline $\log$ & The natural logarithm \\
\hline$N_{\text {occ }}$ & The number of occupants in the home \\
\hline$N_{\text {appliances }}$ & $\begin{array}{l}\text { The number of the indicated appliances in the home. For some appliances, this } \\
\text { is always either } 0 \text { or } 1 .\end{array}$ \\
\hline Alloc eppolience & $\begin{array}{l}\text { The monthly load allocation factor for the indicated appliance (see Lee et al. } \\
\text { 1995) }\end{array}$ \\
\hline IncomeLow & A dummy variable indicating household income is less than $\$ 25,000$ per year \\
\hline IncomeHigh & A dummy variable indicating household income is greater than $\$ 40,000$ per year \\
\hline IsOccDaytime & A dummy variable indicating the home is occupied during the day \\
\hline IsZone1 & A dummy variable indicating the home is sited in $\mathrm{CZ} 1$ \\
\hline HasAC & A dummy variable indicating the presence of an air conditioner \\
\hline HasElecOnly & $\begin{array}{l}\text { A dummy variable indicating the home has electric resistance heat with no } \\
\text { backup system }\end{array}$ \\
\hline HasElec\&Wood & $\begin{array}{l}\text { A dummy variable indicating the home has electric resistance heat with a wood- } \\
\text { burning backup system }\end{array}$ \\
\hline HasElec\&Other & $\begin{array}{l}\text { A dummy variable indicating the home has electric resistance heat with an } \\
\text { unspecified backup system }\end{array}$ \\
\hline HasHPonly & A dummy variable indicating the home has a heat pump with no backup system \\
\hline HasHP\&Wood & $\begin{array}{l}\text { A dummy variable indicating the home has a heat pump with a wood-burning } \\
\text { backup system }\end{array}$ \\
\hline CDD & Cooling-degree days for each month based on NOAA data \\
\hline HDD & Heating-degree days for each billing period, reference temperature $65^{\circ} \mathrm{F}$ \\
\hline UA & Building envelope load coefficient plus infiltration UA \\
\hline IsMAP & A dummy variable indicating a MAP home \\
\hline C & A constant to give the UA*HDD terms units of $k W h /$ day \\
\hline IsVacant & A dummy variable indicating home was vacant during period \\
\hline
\end{tabular}


TABLE 3.5. Estimated Coefficients in Equation 3.1

\begin{tabular}{|c|c|c|c|c|c||}
\hline Coefficient & Value & t-statistic & Coefficient & Value & t-statistic \\
\hline \hline Intercept & -2.15 & -1.76 & $a_{13}$ & 1.66 & 2.74 \\
\hline$a_{1}$ & -2.74 & -2.30 & $a_{14}$ & 1.34 & 3.47 \\
\hline$a_{2}$ & 2.18 & 1.55 & $a_{15}$ & 0.104 & 4.31 \\
\hline$a_{3}$ & 5.01 & 4.36 & $a_{18}$ & 0.0405 & 0.79 \\
\hline$a_{4}$ & 0.39 & 0.36 & $a_{17}$ & 0.322 & 5.24 \\
\hline$a_{5}$ & 2.84 & 2.69 & $a_{18}$ & 0.743 & 43.6 \\
\hline$a_{8}$ & 2.33 & 1.58 & $a_{18}$ & 0.418 & 15.0 \\
\hline$a_{7}$ & 2.20 & 2.54 & $a_{20}$ & 0.291 & 6.82 \\
\hline$a_{8}$ & 3.40 & 3.13 & $a_{21}$ & 0.187 & 4.06 \\
\hline$a_{9}$ & 1.98 & 2.41 & $a_{22}$ & 0.712 & 3.46 \\
\hline$a_{10}$ & 2.91 & 2.82 & $a_{23}$ & 0.583 & 20.0 \\
\hline$a_{11}$ & 0.056 & 0.05 & $a_{24}$ & 0.196 & 1.19 \\
\hline$a_{12}$ & 9.80 & 5.18 & $a_{25}$ & -14.1 & -9.48 \\
\hline \hline $\begin{array}{l}\text { Note: The constraints imposed in this model by using engineering information in } \\
\text { the heating equipment terms limit the usual interpretation of significance based on } \\
\text { the standard t-statistics. }\end{array}$ & & & & \\
\hline \hline
\end{tabular}

First, because no true control or comparison samples are available for estimating energy savings, we define a comparison home based on typical characteristics. The "pre-MAP baseline" home represents a home with dimensions typical of current homes, but with an efficiency level typical of homes built prior to the MAP and Super Good Cents Program: we assume that the envelope conductance value is a $U_{\circ}$ of

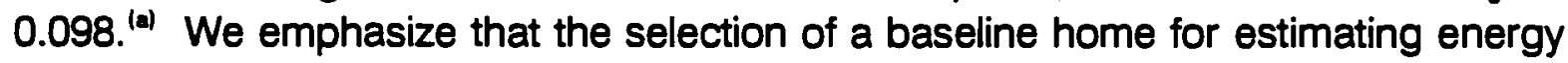
savings is critical in determining program cost-effectiveness and that other choices of home characteristics for calculating energy savings are possible. We believe, however, that the characteristics used here represent the best available information

(a) Eckman, T. 1994; p. 11. Letter with attachments to Angeline Chong, Portland General Electric, dated October 26, 1994, Northwest Power Planning Council, Portland, Oregon. 
about how manufactured homes would have been built in the absence of major regional efficiency programs.

Second, the electricity savings estimates are very sensitive to assumptions made about the use of non-electric (primarily wood) space heat. Our survey data indicate that a substantial proportion (about $20 \%$ ) of our combined sample of electrically heated homes uses some non-electric heat. We find no consistent evidence, however, that more efficient homes, such as those built under MAP, use non-electric heat more often.

To estimate energy savings impacts of MAP, we use two approaches. In the first case, we calculate electricity savings based on the overall observed mix of electric and non-electric heating in homes with central, electric heating systems. These savings

- capture the direct effects on electric utilities and the utility system. In the second case, we calculate energy savings based on the assumption that all heating is supplied by an electric resistance furnace. In this approach, we assume that energy savings in homes using electric resistance heating exclusively are a measure of all energy savings, regardless of the backup fuel used. The latter approach is directly comparable with the method used to estimate pre-program energy savings and is intended to represent the total resource impacts of the program on MAP homes.

Third, the energy savings attributable to MAP should include the market transformation savings induced by the program. These include national savings resulting from HUDcode changes attributable to MAP, and effects on the efficiency of gas-heated manufactured homes and of homes built after MAP ends. Quantifying these effects is beyond the scope of this study, but Chapter 4 discusses this issue in more detail.

The savings estimated in this report are based on the third-tier, regression results. Acquisition energy savings are calculated as the energy consumption difference between pre-program baseline and MAP homes. These are the direct energy savings associated with homes built under MAP. These energy savings are distinguished from market transformation energy savings that result from the market transformation effects of the program. 


\subsection{COST-EFFECTIVENESS ANALYSIS}

We assess the cost-effectiveness of MAP through a procedure specified by Bonneville (BPA 1993). Bonneville determines the cost-effectiveness of demand-side management programs by comparing the levelized price of the energy saved with the levelized avoided cost of Bonneville's alternative electricity resource. The methodology only takes acquisition energy savings into account.

A real levelized purchase price expresses all the payments for the resource as an equal payment per kWh of energy savings (BPA 1993). The levelized purchase price is calculated by dividing the present value of all program costs by the present value of program savings.

We calculate costs two ways. The primary method is using regional system cost (a resource's real levelized regional cost plus or minus four adjustments that quantify indirect cost effects of a resource) perspective, as recommended by Bonneville. These adjustments account for capacity, seasonality, on/off peak, and resource life. For MAP, the adjustment is $-0.85 \mathrm{c} / \mathrm{kWh}$ (1993\$). This program cost-effectiveness test is basically equivalent to the Total Resource Cost test. As noted earlier, however, Bonneville's methodology does not include explicitly any market transformation benefits of the program. To estimate the regional system cost we use our estimates of energy savings as described in Section 3.4. The current cost-effectiveness limit is 4.36/kWh (1993\$) (BPA 1993). The adjusted regional system cost should be equal to or less than this limit for MAP to be cost-effective.

We also estimate levelized costs using the Bonneville system cost perspective. This method excludes consumer costs. To estimate the Bonneville system cost we use our estimates of electriclty savings as described in Section 3.4. BPA (1993) presents $2.4 \mathrm{c} / \mathrm{kWh}$ as the Bonneville system levelized cost target averaged over all conservation programs. We use this as a measure of MAP cost-effectiveness.

The levelized purchase prices are calculated using a spreadsheet provided by Bonneville. The levelized costs are adjusted with the cost adjustments presented above. 


\subsection{ACQUISITION ENERGY SAVINGS AND COST-EFFECTIVENESS RESULTS}

This chapter summarizes our estimates of the direct acquisition energy savings attributable to MAP and associated levelized costs. These results exclude market transformation impacts, which are discussed in Chapter 5.

\subsection{ACQUISITION ENERGY SAVINGS ESTIMATES}

Table 4.1 summarizes our energy savings estimates for homes built under both phases of MAP. The table presents savings estimates based on use of 1) the mix of heating types in our sample and 2) electric resistance heating only.

TABLE 4.1. MAP Acquisition Energy Savings, kWh/year per home

\begin{tabular}{|c|c|c|c|c|}
\hline \multirow{2}{*}{$\begin{array}{l}\text { Climate } \\
\text { zone }\end{array}$} & \multicolumn{2}{|c|}{ Phase 1} & \multicolumn{2}{|c|}{ Phase 2} \\
\hline & $\begin{array}{l}\text { All heating } \\
\text { types }\end{array}$ & $\begin{array}{l}\text { Electric } \\
\text { resistance } \\
\text { heating }\end{array}$ & $\begin{array}{l}\text { All heating } \\
\text { types }\end{array}$ & $\begin{array}{l}\text { Electric } \\
\text { ressistance } \\
\text { heating }\end{array}$ \\
\hline 1 & $\begin{array}{c}3,063 \\
( \pm 600) \\
2.08 \mathrm{kWh} / \mathrm{ft}^{2}\end{array}$ & $\begin{array}{c}3,961 \\
( \pm 700) \\
2.69 \mathrm{kWh} / \mathrm{ft}^{2}\end{array}$ & $\begin{array}{c}2,029 \\
( \pm 690) \\
1.38 \mathrm{kWh} / \mathrm{ft}^{2}\end{array}$ & $\begin{array}{c}2,524 \\
( \pm 780) \\
1.72 \mathrm{kWh} / \mathrm{tt}^{2}\end{array}$ \\
\hline 2 & $\begin{array}{c}4,497 \\
( \pm 900) \\
3.06 \mathrm{kWh} / \mathrm{ft}^{2}\end{array}$ & $\begin{array}{c}5,526 \\
( \pm 980) \\
3.76 \mathrm{kWh} / \mathrm{ft}^{2}\end{array}$ & $\begin{array}{c}2,936 \\
( \pm 1,000) \\
2.00 \mathrm{kWh} / \mathrm{ft}^{2}\end{array}$ & $\begin{array}{c}3,522 \\
( \pm 1,090) \\
2.40 \mathrm{kWh} / \mathrm{tt}^{2}\end{array}$ \\
\hline 3 & $\begin{array}{c}5,719 \\
( \pm 1,080) \\
3.89 \mathrm{kWh} / \mathrm{ft}^{2}\end{array}$ & $\begin{array}{c}6,300 \\
( \pm 1,110) \\
4.29 \mathrm{kWh} / \mathrm{ft}^{2}\end{array}$ & $\begin{array}{c}3,672 \\
( \pm 1,200) \\
2.50 \mathrm{kWh} / \mathrm{ft}^{2}\end{array}$ & $\begin{array}{c}4,015 \\
( \pm 1,240) \\
2.73 \mathrm{kWh} / \mathrm{tt}^{2}\end{array}$ \\
\hline Region & $\begin{array}{c}3,814 \\
( \pm 470) \\
2.59 \mathrm{kWh} / \mathrm{ft}^{2}\end{array}$ & $\begin{array}{c}4,725 \\
( \pm 530) \\
3.21 \mathrm{kWh} / \mathrm{ft}^{2}\end{array}$ & $\begin{array}{c}2,500 \\
( \pm 530) \\
1.70 \mathrm{kWh} / \mathrm{ft}^{2}\end{array}$ & $\begin{array}{c}3,012 \\
( \pm 580) \\
2.05 \mathrm{kWh} / \mathrm{ft}^{2}\end{array}$ \\
\hline \multicolumn{5}{|c|}{$\begin{array}{l}\text { Notes: Numbers in parentheses indicate an approximate } 95 \% \text { confidence interval } \\
\text { based on the regression analysis coefficients. See Lee et al. (1995) for a } \\
\text { discussion of the calculation. Normalized savings are based on the typical floor } \\
\text { area used in our analysis. }\end{array}$} \\
\hline
\end{tabular}


As noted in Chapter 3, we estimate energy savings in two ways. In the first, we calculate electricity savings based on the mix of all heating types in our combined sample. These savings capture the direct effects on electric utilities and the utility system. In the second way, we calculate energy savings based on the assumption that all heating is supplied by an electric resistance furnace. The latter approach is directly comparable with the method used to estimate pre-program energy savings and is intended to represent the total resource impacts of the program on MAP homes. Table 4.1 presents savings estimates for both cases.

The Phase 1 results can be compared with our simple billing data analysis. Comparing the unadjusted billing data regional savings estimates (Table 3.1) with the results in Table 4.1 for all heating types shows that the Phase 1 regional savings suggested by the raw billing data are $53 \%$ less than the results from our detailed model. This difference probably can be attributed to variations between the characteristics of baseline and MAP homes, particularly differences in use of nonelectric heat. Small sample sizes in CZ 3 greatly increase the uncertainty in the simple billing data comparison.

Comparing our simple billing data regression-adjusted results in Table 3.1 with the Phase 1 results in Table 4.1, however, shows very good agreement (within 10\% for the region). Within climate zones the savings estimates from the two methods differ more, up to about $35 \%$, but this relatively close agreement suggests that a simplified annual regression model may be a good first-order method of estimating energy savings.

The Phase 1 results also can be compared with our PRISM analysis. Comparing the Table 4.1 results for all fuels with the unfiltered PRISM results (Table 3.2) shows that the PRISM savings estimates are lower across all climate zones; regionally, the PRISM savings estimates are about $51 \%$ of the estimates in Table 4.1. Comparing the electric resistance heating results in Table 4.1 with the filtered PRISM results (Table 3.3) also shows that the PRISM savings estimates are lower than our detailed regression model estimates; regionally, the PRISM savings estimates are about $40 \%$ of the estimates in Table 4.1. The differences are likely due to known biases in the PRISM estimates, small sample sizes, and dissimilarities between MAP and baseline homes that are not accounted for in the PRISM analysis.

It is also informative to compare our Phase 1 estimates with the pre-program savings estimates. Because the pre-program estimates are based on electric resistance furnace heating, we compare the MAP Phase 1, electric resistance savings estimates in Table 4.1 with Baylon and Davis 1993 (Table 8). Across the climate zones, our 
savings estimates are about $71 \%$ of the pre-program estimates. Possible reasons for the differences are discussed in Chapter 6.

MAP Phase 2 is the period after the program specifications were changed in response to the new HUD code. Again, we calculate savings based on both the mix of heating types observed in our sample and electric resistance furnaces only. The savings during Phase 2 average about 64\% of the savings during Phase 1.

\subsection{ACQUISITION COST-EFFECTIVENESS}

Several factors have to be considered when assessing the cost-effectiveness of MAP. Bonneville's methodology (BPA 1993) focuses on the adjusted regional system levelized cost of acquisition energy savings. A major intent of MAP, however, was to transform the manufactured housing energy efficiency market; therefore, the market transformation benefits should be included in the cost-effectiveness assessment. A comprehensive study of these benefits is beyond the scope of this study, however, but Chapter 5 discusses them conceptually. In this section, we consider only the energy savings from homes built under MAP - the acquisition energy savings - and their associated levelized costs.

Cost-effectiveness needs to be based on energy savings minus the effect of "free riders." In this case, a free rider is a person who would have bought a MAP home without the utility payment to the manufacturer; thus, because of the utility payment, he or she is getting a "free ride." Because manufactured homes as efficient as MAP homes were unavailable before MAP and the Super Good Cents Program, pure free riders are essentially non-existent. Buyers who would have bought relatively efficient homes, however, could be considered to be "partial" free riders. However, using the market average efficiency level purchased, instead of the minimum level available, as our reference point for estimating savings largely accounts for this effect.

In addition to energy savings, program costs are required to calculate the levelized cost of the energy savings and to assess cost-effectiveness. The energy efficiency measure costs that we use are based on Baylon and Davis (1993) and updated data ${ }^{(a)}$. Table 4.2 summarizes the costs.

(a) Personal communication, D. Baylon, Ecotope, November 1, 1994. The main cost changes are a decrease in efficient window costs and an assumption that baseline home walls have dimensions adequate to install R-19 insulation. 
Although we do not have definitive information about how the utility payment to manufacturers has affected the pricing of MAP homes, two points are important:

- The utility payment to the manufacturers during Phase 1 probably exceeds the manufacturers' additional costs. The cost data suggest that the incremental wholesale cost of Phase 1 MAP homes is around $\$ 2,000$, which is about $\$ 500$ less than the utility payment to the manufacturers; the manufacturers' incremental material cost is probably only about $\$ 1,400$, on the average (Harkreader, Lee, and Sherman 1987).

- The desired leveraging of the utility payment probably did not occur consistently. Survey data suggest that some buyers paid extra for the MAP features, even though manufacturers received the $\$ 2,500$ payment for each home (Sandahl, Lee, and Chin 1995). For the 15\% of respondents who recalled paying a specific amount more for a MAP home, they paid an average of $\$ 1,800$ for the MAP features.

TABLE 4.2. Costs Used in Levelized Cost Analysis

\begin{tabular}{||l|c|c||}
\hline Cost Component & $\begin{array}{c}\text { Phase 1 cost per } \\
\text { home (1993\$) }\end{array}$ & $\begin{array}{c}\text { Phase 2 cost per } \\
\text { home (1993\$) }\end{array}$ \\
\hline \hline $\begin{array}{l}\text { Incremental MAP home costs to } \\
\text { consumer (retail costs) }\end{array}$ & $\$ 2,633$ & $\$ 1,943$ \\
\hline Utility payment to manufacturer & $\$ 2,500$ & $\$ 1,500$ \\
\hline $\begin{array}{l}\text { Administrative costs (including program } \\
\text { evaluation cost) }\end{array}$ & $\$ 133$ & $\$ 133$ \\
\hline
\end{tabular}

For purposes of calculating MAP's levelized cost, we assume that the MAP payment directly offsets retail price rather than wholesale price or manufacturer's cost. We assume that the buyer finances the remainder. Some of Bonneville's costs are expensed and some are financed. All costs are translated into present discounted values.

Table 4.3 presents our estimates of MAP acquisition levelized costs based on the two different perspectives. In all cases, MAP is more cost-effective in the colder climate zones because energy savings are larger, but costs are the same. 
From the Bonneville system perspective, both phases of MAP are cost-effective in CZs 2 and 3. In CZ 1, Phase 2 is marginally cost-effective, but Phase 2 exceeds the costeffectiveness level slightly from the Bonneville system perspective. Averaging over the region, each phase is cost-effective, as are both phases combined from the Bonneville system perspective.

TABLE 4.3. MAP Acquisition Levelized Costs, \&/kWh (1993\$)

\begin{tabular}{||l|c|c|c|c|c|c||}
\hline \hline \multirow{2}{*}{$\begin{array}{l}\text { Climate } \\
\text { zone }\end{array}$} & $\begin{array}{c}\text { Bonneville } \\
\text { system }\end{array}$ & $\begin{array}{c}\text { Regional } \\
\text { system }\end{array}$ & $\begin{array}{c}\text { Bonneville } \\
\text { system }\end{array}$ & $\begin{array}{c}\text { Regional } \\
\text { system }\end{array}$ & $\begin{array}{c}\text { Bonneville } \\
\text { system }\end{array}$ & $\begin{array}{c}\text { Regional } \\
\text { system }\end{array}$ \\
\cline { 2 - 7 } & 2.81 & 2.11 & 2.36 & 2.37 & 2.73 & 2.15 \\
\hline 1 & 1.64 & 1.27 & 1.37 & 1.46 & 1.59 & 1.30 \\
\hline 3 & 1.11 & 1.01 & 0.92 & 1.18 & 1.08 & 1.04 \\
\hline Region & 2.09 & 1.63 & 1.75 & 1.85 & 2.03 & 1.67 \\
\hline \hline
\end{tabular}

From the regional system perspective (including customer and utility cost and accounting for all energy savings in MAP homes), MAP's levelized cost is far below the cost-effectiveness threshold. Regionally, MAP's levelized acquisition cost during Phase 1 is $62 \%$ below the cost-effectiveness threshold and during Phase 2 it is $60 \%$ below the threshold. For both phases combined, the acquisition levelized cost is $61 \%$ below the threshold. ${ }^{(0)}$

(a) To assess whether possible fuel switching from natural gas to electric heat resulting from MAP could have affected program cost-effectiveness, we conducted a simplified analysis. A previous study (Lee, Sandahl, and Kavanaugh 1994) estimated that MAP could have induced some fuel switching, up to a maximum of about $6 \%$ of new homes. Using the data from the current study and the methodology in BPA $(1993$, p. 12), we estimate that up to $12 \%$ fuel switching from natural gas to electric heat could have been induced by MAP and it would have remained cost-effective from the regional perspective. Thus, fuel switching could increase program levelized cost, but not beyond the regional cost-effectiveness level. 


\subsection{MARKET TRANSFORMATION IMPLICATIONS}

MAP was designed to have significant, long-term effects on the manufactured housing market. The program was intended to provide an initial boost to the market and then either be terminated or redesigned. MAP's features were consistent with prerequisites for demand-side market transformation programs. Its scope makes MAP one of the largest market transformation programs conducted so far.

The scope of our evaluation, however, did not include a comprehensive assessment of the market transformation effects of MAP. The energy savings impacts and costeffectiveness results presented earlier captured only the direct consequences of acquiring energy efficiency in MAP homes and provided no information about MAP's market transformation effects.

Figure 5.1 illustrates the general effects attributed by Nadel and Geller (1994) to market transformation programs. The figure shows the market penetration of super efficient manufactured homes with and without MAP. With MAP, the penetration of MAP-level efficient electrically heated manufactured homes went from $0 \%$ to $100 \%$ of the market between April and October 1992. During the remaining years of the program, $100 \%$ of the homes were built to MAP efficiency levels. The figure shows a decline in the penetration of efficient

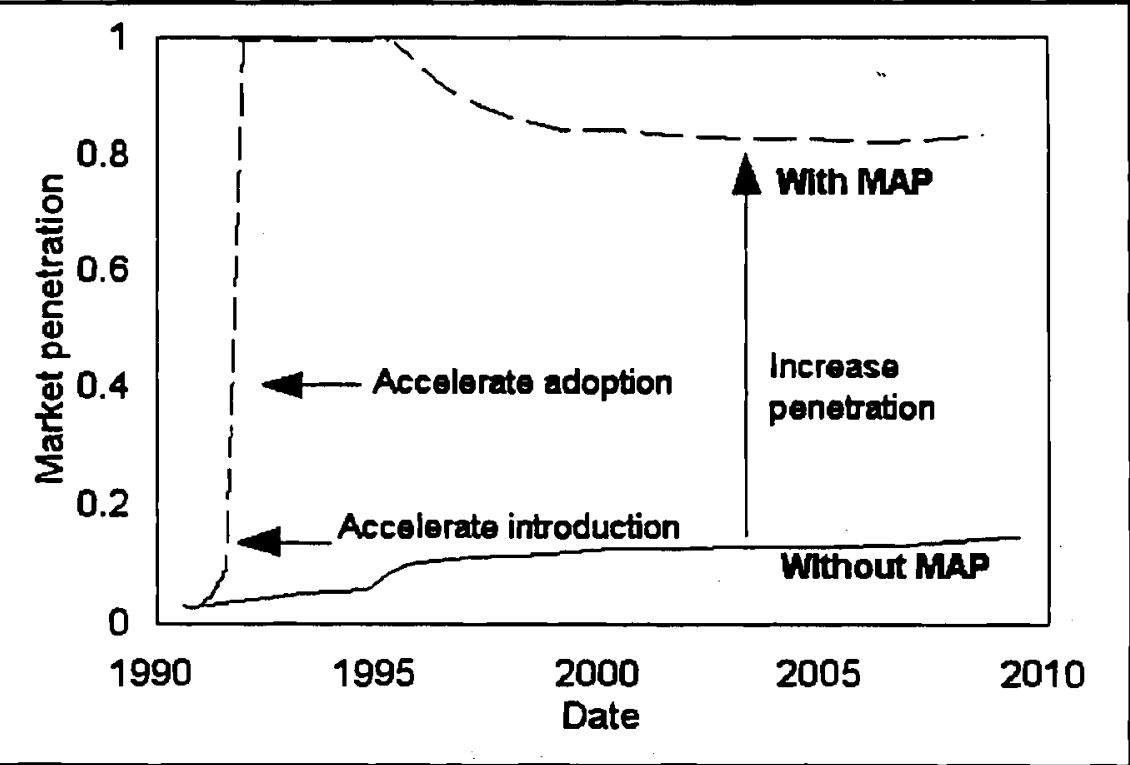

FIGURE 5.1. Components of Market Transformation homes and a leveling off at about $80 \%$ after the program ends. Because we have no data on what the market will look like after the program, this response is strictly hypothetical and illustrative. The lower curve illustrates what might have happened without MAP occurring. The penetration of MAP-level homes is zero percent at first. It then increases slightly and tends to stabilize at around $10 \%$ of the market. Although 
this behavior is consistent with past market trends, the curve shown is hypothetical because we have no data for what would have occurred without MAP.

The two curves in Figure 5.1 highlight three major market transformation phenomena. First, the program accelerated the introduction of high-efficiency manufactured homes. Prior to the program, no homes were being built to MAP levels. ${ }^{\text {(a) }}$ Without the program ever occurring, the lower curve suggests that it might have taken one or two years before the first MAP-equivalent homes would have been built. Second, the program accelerated the adoption of the MAP efficiency levels. The steep rise in the penetration of MAP homes under the program demonstrates this effect. Third, MAP has undoubtedly increased the penetration of high efficiency homes in the market in the long run. Figure 5.1 illustrates this effect as the gap between the long-run market penetration of MAP homes with and without the program.

These three effects provide an informative taxonomy of market transformation impacts. In practice, however, assessment of market transformation impacts is more complex and diverges some from the framework set forth by Nadel and Geller (1994). For program participants, the first two effects - accelerated introduction and adoption - can be considered as the acquisition effects of MAP. These are the actions that the utility payments cause directly and their costs and benefits are captured through the acquisition cost-effectiveness analysis. In a program such as MAP, however, the sheer breadth of the program can cause fundamental market changes, or transformations, as a result of the acquisition phase. These changes become the foundation for both short-term (such as building code upgrades) and long-term market transformations. The remainder of this chapter discusses these impacts associated with MAP.

The major market transformation consequences of MAP that would have an effect on cost-effectiveness included the following: 1) reduced energy conservation measure costs, 2) increased energy code requirements, and 3) residual increases in typical efficiency levels after MAP ends.

No data were collected in this study on the first effect. However, a survey of window costs suggested that during MAP, vinyl window costs decreased about $5 \%$ from their level prior to MAP. ${ }^{(b)}$

(a) This statement must be qualified slightly because the Super Good Cents Program was in effect prior to MAP, and it required efficiency levels comparable to MAP.

(b) Personal communication, David Baylon, Ecotope, November 1, 1994. 
There was some evidence that the second effect occurred: HUD adopted a more efficient energy code, in part because of regional programs including MAP. HUD was kept informed about Bonneville's programs as the HUD code was being developed and adopted. Very likely, regional program experiences helped justify HUD's adoption of an efficiency level that was $14 \%$ more efficient than the level proposed by the industry (MHI 1989).

The third effect, post-MAP persistence of higher efficiency levels, cannot be assessed accurately until the program ends. However, we examined this effect conceptually. Figure 5.2 illustrates the potential market transformation effects. ${ }^{(\boldsymbol{a})}$ The cumulative

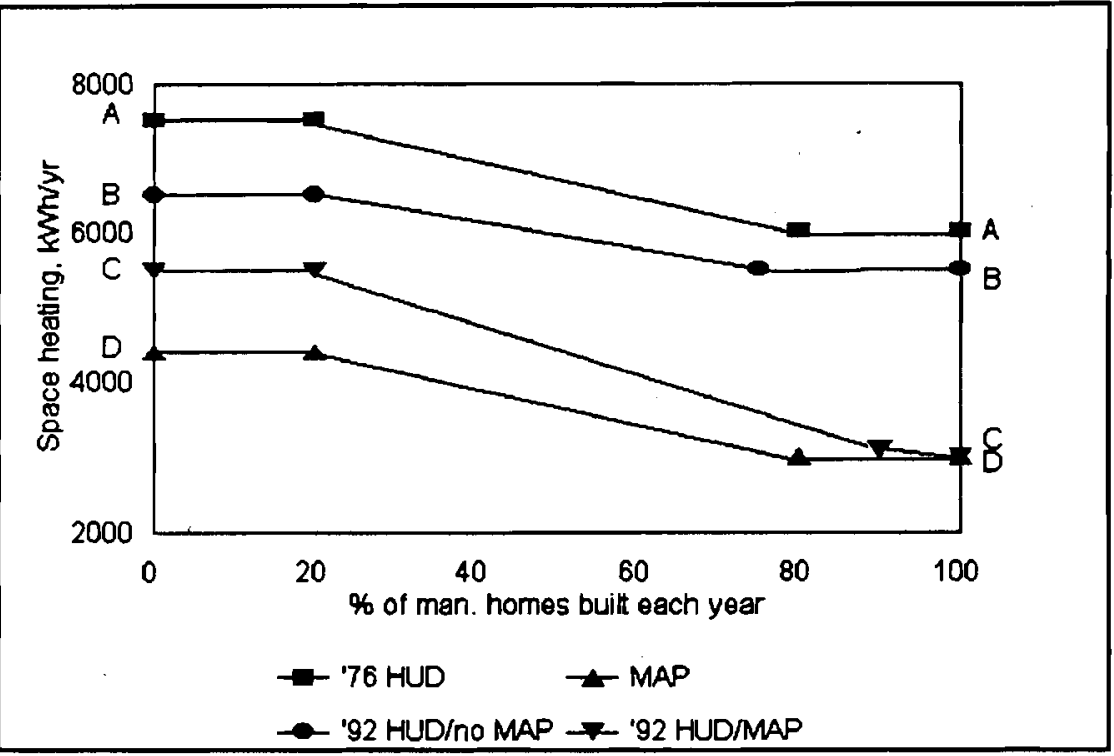

FIGURE 5.2. New Home Energy Use Scenarios market shares for different space heating energy use levels are shown under different conditions. Curve AA shows the market shares under the 1976 HUD code. A small share of homes is built to the lowest efficiency level (consuming the largest amount of energy for space heating), most are in the middle efficiency range, and $a$ few are built to higher efficiency levels. Curve DD shows the

market shares under MAP. The curve is relatively flat; no homes consume more energy than the maximum allowed by MAP and a few consume less space heating energy. Curve BB illustrates what the energy consumption distribution might have looked like under the new HUD code if MAP had never been implemented. The maximum heating energy use is less than the 1976 HUD code maximum, and the rest of the homes consume less. Curve $C C$ illustrates one view of how the market might look after MAP ends. Because MAP influenced the efficiency level adopted by HUD, the maximum energy use is less than under the HUD code if MAP had never been implemented. The minimum energy use is at the lowest levels under MAP because

(a) Note that the numbers shown in Figures 5.2 and 5.3 are only illustrative. 
some manufacturers would continue to offer and some consumers would continue to buy super-efficient homes after MAP ends.

Figure 5.3 uses the same graphical representation to show MAP acquisition energy savings and market transformation savings. The area between curves $A A$ and $D D$ corresponds to the acquisition savings. These savings, however, are for only those homes built during the program. The area between curves BB and CC represents the savings from homes constructed after MAP ends. These savings would occur in all homes built for some period after the program ends.

The energy savings and cost-effectiveness results presented earlier took into account only the acquisition savings attributable to MAP (the difference between curves AA and $D D)$, i.e., energy savings for only those homes constructed during the program.

Because MAP was intended to transform the manufactured housing market for energy efficiency, baseline efficiency levels would probably increase during each year of the program. In fact, the new HUD code went into effect halfway through MAP causing direct program savings relative to the code to decrease. The terms of the program were renegotiated and the cost-effectiveness of

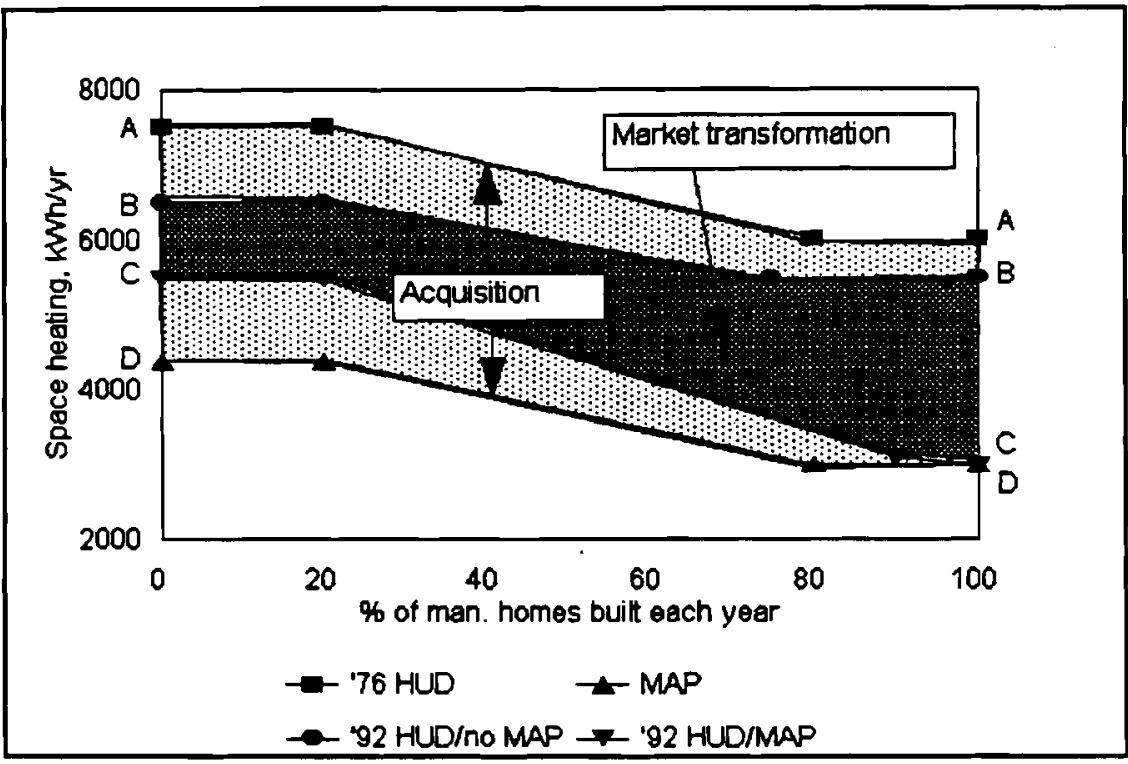

FIGURE 5.3. Acquisition and Market Transformation Energy Savings acquisition savings from the program changed. However, any judgment about cost-effectiveness based on acquisition effects alone is inadequate because market transformation effects are ignored. The market transformation energy savings represented in Figure 5.3 can affect program cost-effectiveness. These savings represent the efficiency increases that would remain in homes built after MAP ends.

Because the program had not ended when this analysis was conducted, we could assess only speculatively the market transformation energy savings attributable to 
MAP. To derive a conservative savings estimate, we assume that homes built for only five years after the program ends will be more efficient because MAP had been implemented. The residual efficiency improvements can be considered to be the future free driver effects of MAP.

Instead of trying to determine the market transformation savings, we conducted a simplified sensitivity analysis of various levels of savings. This analysis takes the Bonneville system perspective. Under this perspective, the utility has no costs after the program ends due to free driver actions, but the energy savings that result from market transformation reduce the future energy load faced by the utility. Table 5.1 shows Bonneville system levelized costs as a function of the percentage decrease in average $U_{0}$ relative to the difference between the HUD-code level $(0.079)$ and the MAP level (0.054). For every $20 \%$ decrease in the difference between the HUD-code and MAP thermal efficiency level, the program levelized costs would decline about $15 \%$. Although we don't know exactly what measures consumers will continue to purchase after MAP ends, early indications are that about half the homes will be built to MAP specifications. ${ }^{\left({ }^{a)}\right.}$ Assuming that this mix of efficiency levels occurs, the program's Bonneville system levelized cost, including both acquisition and market transformation effects, would be about $1.2 \mathrm{c} / \mathrm{kWh}$, or only $60 \%$ of the levelized cost without any market transformation effects. Note that this analysis conservatively takes no credit for MAP increasing the new efficiency level adopted by HUD.

TABLE 5.1. Market Transformation Effect on Bonneville System Levelized MAP Costs

\begin{tabular}{|c|c|c|c|c|c|}
\hline \multicolumn{6}{|c|}{ Residual Efficiency Improvement } \\
\hline $0 \%$ & $20 \%$ & $40 \%$ & $60 \%$ & $80 \%$ & $100 \%$ \\
\hline $2.03 \mathrm{c} / \mathrm{kWh}$ & $1.68 \mathrm{c} / \mathrm{kWh}$ & $1.336 / \mathrm{kWh}$ & $1.06 \mathrm{c} / \mathrm{kWh}$ & $0.836 / \mathrm{kWh}$ & $0.536 / \mathrm{kWh}$ \\
\hline
\end{tabular}

This analysis indicates that the market transformation effects of MAP can have a significant effect on the cost-effectiveness of the program overall. By motivating longrun changes in energy efficiency, resulting in substantial free driver effects, the utilities in the region benefit because they incur no additional program costs, yet they experience large load reductions. The cost-effectiveness of MAP benefits from these long-term, market changing effects, although they are difficult to quantify prospectively.

(a) Some sources have suggested most recently that over $90 \%$ of the homes will be built to MAP levels in certain areas. 


\subsection{FINDINGS AND RECOMMENDATIONS}

This chapter discusses the key findings and conclusions from this evaluation. It also presents recommendations based on the evaluation.

\subsection{EVALUATION FINDINGS}

Based on our analysis, MAP has been cost-effective to the region, even when viewed as just an acquisition program. From the regional system perspective, levelized costs of acquiring energy savings in MAP homes are less than half the $4.3 \% / \mathrm{kWh}$ threshold. Both phases of MAP (pre- and post-1994 HUD code) have been cost-effective from the regional system perspective.

The required levelized cost threshold is lower from the Bonneville system perspective, and MAP is less cost-effective from this perspective. MAP exceeds the threshold by $14 \%$ in $C Z 1$, when viewed strictly as an acquisition program. However, for the other climate zones and all regions combined, the program meets the Bonneville average conservation levelized cost target.

These results hold despite the fact that utility payment leveraging does not appear to have been as successful as desired. If the desired leveraging had occurred, the utilities might have been able to pay the manufacturers less, thus making the program even more cost-effective.

MAP cost-effectiveness cannot be assessed adequately without considering the market transformation impacts of the program. A primary purpose of the program was to make fundamental changes in the market that would institutionalize energyefficiency improvements. Manufacturer representatives anticipate, in fact, that they will continue to offer homes with MAP efficiency levels when MAP ends. ${ }^{(a)}$ Market recognition and consumer acceptance of MAP and Super Good Cents manufactured homes appear to be widespread, and many home buyers are likely to continue purchasing MAP homes. The associated market transformation energy savings of homes produced after the program ends should be included in calculations of MAP's levelized cost. Our simplified, conservative analysis suggests that market transformation effects reduce the overall program levelized costs substantially, making

(a) Personal communication, Joan Brown, Washington Manufactured Housing Association, April 27, 1995. 
the program cost-effective in all cases. This even includes in $C Z 1$, where acquisition cost-effectiveness is questionable from the Bonneville system perspective. Overall, including these market transformation effects is likely to reduce Bonneville's system cost to about $1.2 \% / \mathrm{kWh}$, or about one half the target level.

\subsection{COMPARISON WITH OTHER RESULTS}

Our MAP acquisition energy savings estimates lie between those from two other studies: the pre-program study estimates are based on the results from a simulation model; the second study uses an analysis similar to the one that we applied.

The pre-program energy savings estimates for a Phase 1 MAP home average 6,700 $\mathrm{kWh} /$ year across the Bonneville service territory (between $5,700 \mathrm{kWh} /$ year and 8,900 $\mathrm{kWh} /$ year by climate zone) (Baylon and Davis 1993). As noted earlier, our savings estimates are about $69 \%$ of these values for homes using only electric resistance furnace heating. There is no single reason to explain the discrepancy between the pre-program estimates and our savings estimates, based on actual billing data. This difference, however, is very consistent with the findings from numerous other evaluations that examined pre-program estimates (Brown and Mihlmester 1994). We have reviewed the pre-program analysis (see Lee et al. 1995) and find that several factors might contribute to the difference between those results and ours. The following list is not a critique of the original analysis, but suggests reasons why the pre-MAP results might differ from ours and areas for possible research to explain the differences:

- The home analyzed in the pre-program study was larger than the average home in our sample.

- The pre-program analysis assumed that ventilation rates were equal in MAP and non-MAP homes, but required mechanical ventilation may have increased the heating load in MAP homes.

- The pre-program analysis did not account for periods when occupants were away from home.

- Zoning, in which some rooms are intentionally or unavoidably kept at lower temperatures, was not modeled in the pre-program analysis.

- The pre-program analysis used an average temperature setpoint to estimate space heating, but this approach would not capture changes in temperature and would affect the heating estimates of MAP and non-MAP homes differently. 
In late 1994, three Pacific Northwest investor-owned utilities funded a study of the impacts of MAP (RER 1994). Their energy savings estimates are less than ours, and are considerably less than the pre-program estimates. For electric resistance furnace heating only, and based on historical typical construction practice, their savings estimates are about $63 \%$ of ours. Under the new HUD code, their savings estimates are only about $43 \%$ of ours. This disparity is particularly surprising because they use a method similar to the one used in our study. Some of the possible reasons for these discrepancies include the following:

- potential constraints in their model that led to biased coefficient and realization rate estimates

- lack of data on the construction characteristics of the actual homes in their sample

- a sample frame (customers of three utilities only) different from ours (customers throughout the Pacific Northwest).

No attempt has been made to validate the energy savings estimates from the two prior studies or our analysis. Overall, our savings estimates appear to follow reasonable patterns relative to weather differences. Our estimated savings are about $43 \%$ higher in $C Z 2$ than in $C Z 1$, corresponding to a similar 40\% difference in HDD. Going from $C Z 2$ to 3 , our savings estimates increase about $20 \%$ and HDD increases about $15 \%$. Our savings estimates for homes with electric resistance furnaces consistently exceed the estimates for homes with heat pumps and homes that use backup heat.

The savings estimates reported in RER (1994) are considerably lower than ours and they do not exhibit the same degree of consistency. In particular, the study almost uniformly reports larger energy savings for homes that use backup heat and homes that have heat pumps rather than electric furnaces. These findings are inconsistent with engineering expectations and raise questions about the overall savings estimates.

\subsection{CONCLUSIONS AND RECOMMENDATIONS}

The three-tier approach that we use in this study has proven to be very effective. It relies on a relatively small sample of homes, but incorporates comprehensive occupant and home characteristics data. Utilities usually have available many of the data elements that we used, thus minimizing data acquisition needs. 
The first tier's raw billing data analysis provided an indication that energy savings were well below pre-program projections. The simple regression approach used in the firsttier analysis required a minimal amount of data to adjust annual electricity bills to account for some of the important differences between MAP and baseline homes. This analysis showed that building shell area and the use of non-electric backup heat were important determinants of electricity use that should be accounted for in estimating energy savings.

Our PRISM results provided estimates of "heating" (temperature-sensitive) energy consumption and base load consumption. Without filtering out homes that were not modeled well by PRISM, the PRISM estimates exhibited large standard errors; the standard errors of estimated savings exceeded the average estimated savings in all three climate zones. When the homes that PRISM did not fit well were filtered out (thus excluding about $40 \%$ of the observations), the standard errors decreased substantially in most cases. Our PRISM base load consumption estimates ranged from around $8,000 \mathrm{kWh} /$ year to $9,900 \mathrm{kWh} /$ year. These estimates were lower than the measured non-heating consumption of about 10,000 kWh/year reported in Lee et al. (1988), and also lower than the $11,500 \mathrm{kWh} /$ year total of mean water heating and other appliance metered energy consumption reported in Onisko, Roos, and Baylon (1993, Tables 13 and 20). These results suggested that the PRISM estimates of "heating" included other loads that were part of the base load, and the "heating" estimates could not be used to estimate energy savings accurately. Furthermore, the PRISM analysis did not allow us to control for any of the differences between MAP and baseline homes, or to estimate savings relative to pre-program baseline homes. The PRISM analysis was useful, however, for gaining a better understanding of the billing data and factors that affected electricity consumption.

The third-tier analysis, a more complete regression model, took the most factors into account in the estimates and provided the most flexibility to estimate energy use under a variety of conditions. The model provided a useful tool that allowed us to estimate energy consumption for different homes and households, and to estimate energy savings relative to different baseline homes.

This study has raised several important analytic issues that were critical in this evaluation of MAP and should be explored in future activities. These issues are presented below along with suggested investigations to resolve them:

- Program cost-effectiveness is very sensitive to the energy efficiency assumed for the pre-program baseline manufactured homes: We used the best available information to estimate the efficiency of manufactured homes that would have been built in the absence of the Super Good Cents Program and MAP. 
Research should be conducted to identify underlying industry efficiency trends and disentangle them from the effects of regional utility energy-efficiency programs.

- The energy savings estimates from the pre-program engineering analyses differ substantially from our billing-data-based estimates: Baylon and Davis (1993) calibrated their methodology with data from energy-efficient manufactured homes. The methodology should be extended to a sample of standard manufactured homes, such as our baseline sample, to help determine whether the model accurately estimates consumption over a wide range of envelope characteristics.

- The relationship between temperature and energy consumption in regression analysis models needs further investigation: The heating-degree day structure that we and others have used to model the heating portion of total electricity use needs further refinement. The use of heating-degree days based on $65^{\circ} \mathrm{F}$ is not completely consistent with expectations about variations in the reference temperature across houses. The relationship between the coefficients estimated for MAP and control homes needs to be investigated further and other model structures need to be examined.

- Zoning may diminish the effect of building envelope efficiency improvements: The effects of intentional and implicit zoning in all residences may reduce the energy savings associated with energy-efficient homes. This issue should be further studied to determine the potential magnitude of the effect.

- Ventilation differences may have a significant effect on the apparent energy savings of MAP homes: The MAP homes are required to have additional mechanical ventilation, which may add to the heating load. The magnitude of this load should be studied to determine how much effect it has on energy savings.

In addition to analytic findings, this study has produced important program design and policy findings and observations. The major findings are the following:

- On the average, the manufacturer payment may have exceeded the incremental wholesale costs associated with MAP homes: The available cost data suggest that the MAP payment exceeded the average incremental material and wholesale costs associated with MAP homes. The buyer survey data suggest that the pricing of MAP homes led to both the manufacturers and dealers benefitting from the utility payment. This was not the original intent of the program. The effect, however, may have been to "prime the pump," prompting dealer and manufacturer buy-in to the program, which were both absolutely critical for the outstanding implementation success of the program. 
- MAP appears to have achieved its ambitious market transformation goa/s: Available information suggests that MAP has made positive changes to the manufactured housing market in the Pacific Northwest. Consumers are aware of energy-efficient manufactured homes and know that super-efficient homes are available. Dealers have seen that a substantial market exists for energyefficient homes and that buyers associate energy efficiency with quality.

Manufacturers have demonstrated that super efficient manufactured homes can be built. Although no one knows what the market will look like in several years, there are early indications that energy-efficient homes will continue to be a large segment of this market.

- MAP could have benefitted from having an off-the-shelf strategy to transition out of the program: MAP is ending about nine months earlier than planned, without a strategy in place to transition from the utility payments and infrastructure supporting MAP. Numerous parties are working to establish mechanisms to replace the program, but significant disruptions have occurred and the relationships established in the past have been jeopardized. Future market transformation programs should include a transition strategy as part of their overall design. 


\subsection{REFERENCES}

Baylon, D. and B. Davis. 1993. Cost-Effectiveness of the Manufactured Housing Acquisition Program (MAP), Ecotope, Seattle, Washington.

Bonneville Power Administration (BPA). 1993. Energy Conservation Guidebook, DOE/BP-2273, Portland, Oregon.

Brown, M. and P. Mihlmester. 1994. Summary of California DSM Impact Evaluation . Studies, ORNL/CON-403, Oak Ridge National Laboratory, Oak Ridge, Tennessee.

Cahill, J. M., K. G. Ritland, and W. Lin-Kelly. 1992. Description of Electric Energy Use in Single-Family Residences in the Pacific Northwest: 1986-1992, DOE/BP-2018, Bonneville Power Administration, Portland, Oregon.

Gilbertson, W. L., F. V. Di Massa, A. D. Lee, and S. A. Onisko. 1993. A Road Map for Success: How Northwest Manufactured Housing Conservation Efforts Revolutionized an Industry, DOE/BP-2139, Bonneville Power Administration, Portland, Oregon.

Harkreader, S. A., A. D. Lee, and M. P. Sherman. 1987. Current Construction Practice in Pacific Northwest Manufactured Homes and Upgrade Possibilities. DOE/BP-846, Bonneville Power Administration, Portland, Oregon.

Lee, A. D., R. I. Chin, and S. A. Onisko. 1994. "Bridging the Gap: Designing DSM Programs Based on the Difference between Utility and Consumer Economic Perspectives," PNL-SA-24346, Pacific Northwest Laboratory, Richland, Washington, published in Proceedings of the 1994 Summer Study on Energy Efficiency, ACEEE, Washington, D.C.

Lee, A. D., C. C. Conner, J. E. Englin, D. L. Hadley, R. G. Lucas, N. E. Miller, and W. H. Monroe. 1988. Cost-Effectiveness of Conservation Upgrades in Manufactured Homes, PNL-6519, Pacific Northwest Laboratory, Richland, Washington.

Lee, A. D., L. J. Sandahl, and D. C. Kavanaugh. 1994. Fuel Choice Effects of the Manufactured Housing Acquisition Program: A Preliminary Assessment, DOE/BP2350, Bonneville Power Administration, Portland, Oregon. 
Lee, A. D., Z. T. Taylor, D. C. Kavanaugh, R. C. Chin, and L. J. Sandahl. 1995. Manufactured Housing Acquisition Program Evaluation Technical Appendix, PNL10818, Pacific Northwest Laboratory, Portland, Oregon.

Manufactured Housing Institute (MHI). 1989. "MHCSS Proposed Change, MHCSS Consensus Committee, Subpart F," Washington, D.C.

Nadel, S. and H. Geller. 1994. "Market Transformation Programs: Past Results, Future Directions," published in ACEEE 1994 Summer Study on Energy Efficiency, Washington, D.C.

Onisko, S., C. Roos, and D. Baylon. 1993. Non-Space Heating Electrical Consumption in Manufactured Homes, DOE/BP-2140, Bonneville Power Administration, Portland, Oregon.

Regional Economic Research (RER). 1994. Regional Impact Evaluation of Manufactured Home Acquisition Program (MAP), San Diego, California.

Sandahl, L. J., A. D. Lee, and R. I. Chin. 1995. Summary of Manufactured Housing Acquisition Program (MAP) Process Evaluation Survey Results, PNL-10572; Pacific Northwest Laboratory, Richland, Washington. 